\title{
Zoonotic Potential of Influenza A Viruses: A Comprehensive Overview
}

\author{
Ahmed Mostafa ${ }^{1,2}$, Elsayed M. Abdelwhab ${ }^{3}(\mathbb{0})$, Thomas C. Mettenleiter ${ }^{3}(\mathbb{D}$ and \\ Stephan Pleschka ${ }^{1, *}$ \\ 1 Institute of Medical Virology, Justus Liebig University Giessen, Schubertstrasse 81, 35392 Giessen, Germany; \\ Ahmed_elsayed@daad-alumni.de \\ 2 Center of Scientific Excellence for Influenza Viruses, National Research Centre (NRC), Giza 12622, Egypt \\ 3 Institute of Molecular Virology and Cell Biology, Friedrich-Loeffler-Institut, Federal Research Institute for \\ Animal Health, Südufer 10, 17493 Greifswald-Insel Riems, Germany; Sayed.Abdel-Whab@fli.de (E.M.A.); \\ thomas.mettenleiter@fli.de (T.C.M.) \\ * Correspondence: stephan.pleschka@viro.med.uni-giessen.de
}

Received: 9 July 2018; Accepted: 13 September 2018; Published: 13 September 2018

check for updates

\begin{abstract}
Influenza A viruses (IAVs) possess a great zoonotic potential as they are able to infect different avian and mammalian animal hosts, from which they can be transmitted to humans. This is based on the ability of IAV to gradually change their genome by mutation or even reassemble their genome segments during co-infection of the host cell with different IAV strains, resulting in a high genetic diversity. Variants of circulating or newly emerging IAVs continue to trigger global health threats annually for both humans and animals. Here, we provide an introduction on IAVs, highlighting the mechanisms of viral evolution, the host spectrum, and the animal/human interface. Pathogenicity determinants of IAVs in mammals, with special emphasis on newly emerging IAVs with pandemic potential, are discussed. Finally, an overview is provided on various approaches for the prevention of human IAV infections.
\end{abstract}

Keywords: Influenza A virus; zoonosis; pathogenicity; evolution; pandemic

\section{Introduction}

Influenza is a contagious respiratory disease caused by influenza viruses (IVs). IVs are categorized antigenically based on the variations of the nucleoprotein (NP) into four genera: influenza A viruses (IAV), influenza B viruses (IBV), influenza C viruses (ICV), and influenza D viruses (IDV) [1]. Together with Isavirus, Thogotovirus, and Quaranjavirus, they compose the family Orthomyxoviridae. Both human IAV and IBV trigger seasonal global epidemics, while human infections with ICV are less frequent and generally cause mild illness without reported epidemics. IDV mostly infect cattle and are not yet known to infect humans [2].

IVs have a segmented, negative sense, single-stranded (-ss) viral RNA (vRNA) genome. Both IAV and IBV contain eight vRNA segments, while ICV and IDV contain only seven segments [3]. The eight genomic segments of IAV encode at least 10 viral proteins (Figure 1). 


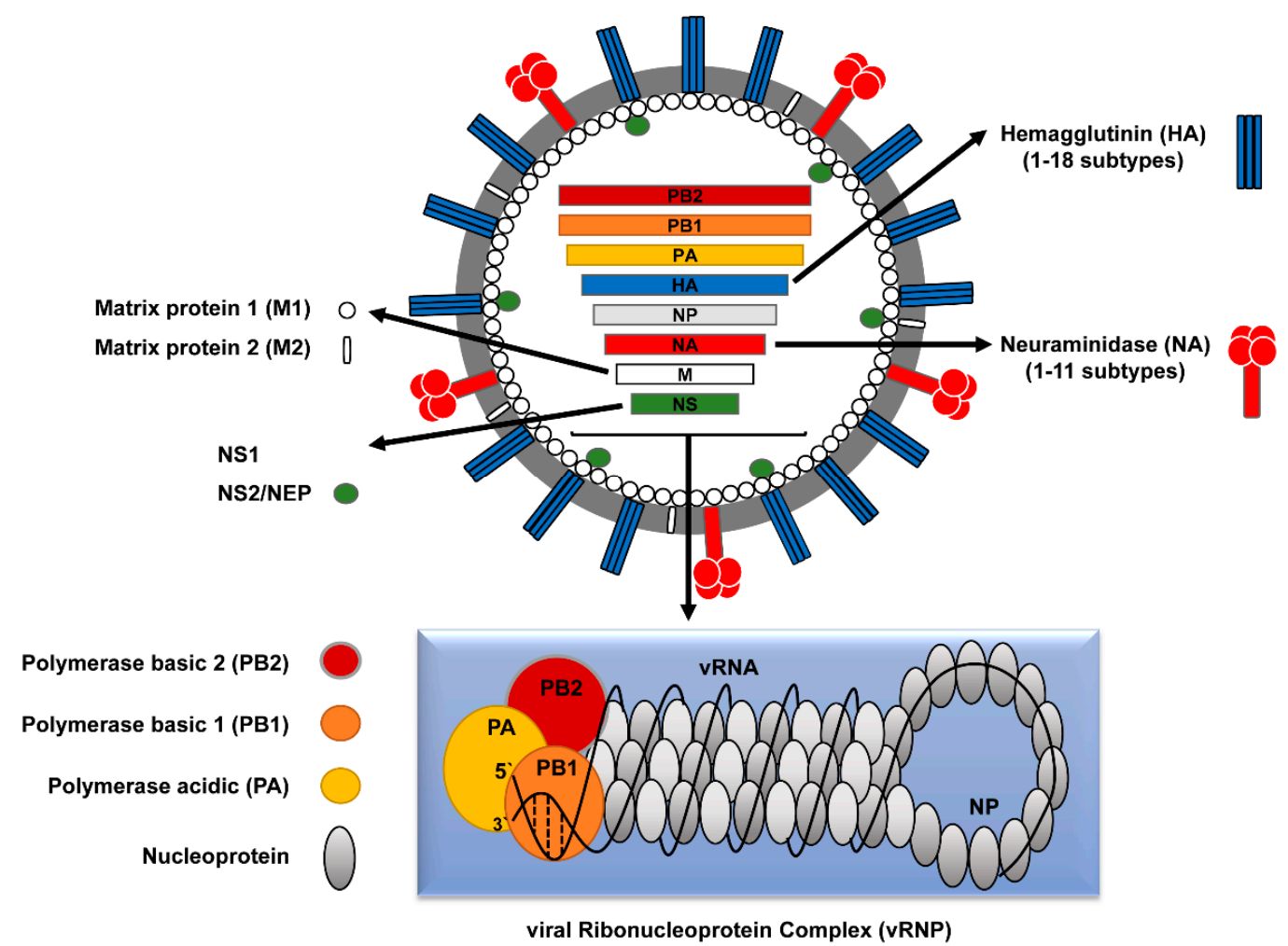

Figure 1. Schematic structure of influenza A virus (IAV). The envelope of the IAV particle, which is derived from the host cell plasma membrane, contains three trans-membrane proteins; two surface glycoproteins designated as hemagglutinin (HA) and neuraminidase (NA) and the proton channel matrix protein 2 (M2). The matrix protein 1 (M1) underlies the inner surface of the viral envelope and associates with NEP and viral ribonucleoprotein complexes (vRNPs). The eight vRNPs comprise eight negative-strand RNA segments associated with the nucleoprotein (NP) and three RdRp polymerase subunits (PA, PB1, PB2).

Each segment encodes at least one structural protein: polymerase basic protein 2 (PB2, segment 1), polymerase basic protein 1 (PB1, segment 2$)$, polymerase acidic protein (PA, segment 3$)$, hemagglutinin (HA, segment 4), nucleoprotein (NP, segment 5), neuraminidase (NA, segment 6), matrix proteins (M1 and M2, segment 7), and non-structural proteins (NS1 and NS2 or nuclear export protein (NEP), segment 8) (Table 1).

The viral envelope contains two viral transmembrane glycoproteins; hemagglutinin (HA, $80 \%$ ) and neuraminidase (NA, $\sim 17 \%$ ). The HA protein forms a trimer, which protrudes approximately $13.5 \mathrm{~nm}$ from the viral surface and has a rod-like shape, while the NA protein forms a tetramer with mushroom-like shape [3-5]. In addition, the IAV envelope contains a small number of an integral tetrameric membrane protein called Matrix protein 2 (M2) with ion channel activity [6]. The Matrix protein 1 (M1) underlies the inner surface of the envelope. Furthermore, the NEP/NS2 protein is detected in minor amounts and is a consistent component of influenza virions [7]. The viral core comprises the eight vRNA segments (890-2341 nucleotides (nt)) in association with the viral nucleoprotein (NP) and the RNA-dependent RNA-polymerase (RdRp) subunits (PB2, PB1, and PA) to constitute the biological active replication/transcription units of influenza virus, called viral ribonucleoprotein (vRNP) complexes [3] (Figure 1 and Table 1). 
Table 1. The genome and functional proteins of influenza A virus (IAV).

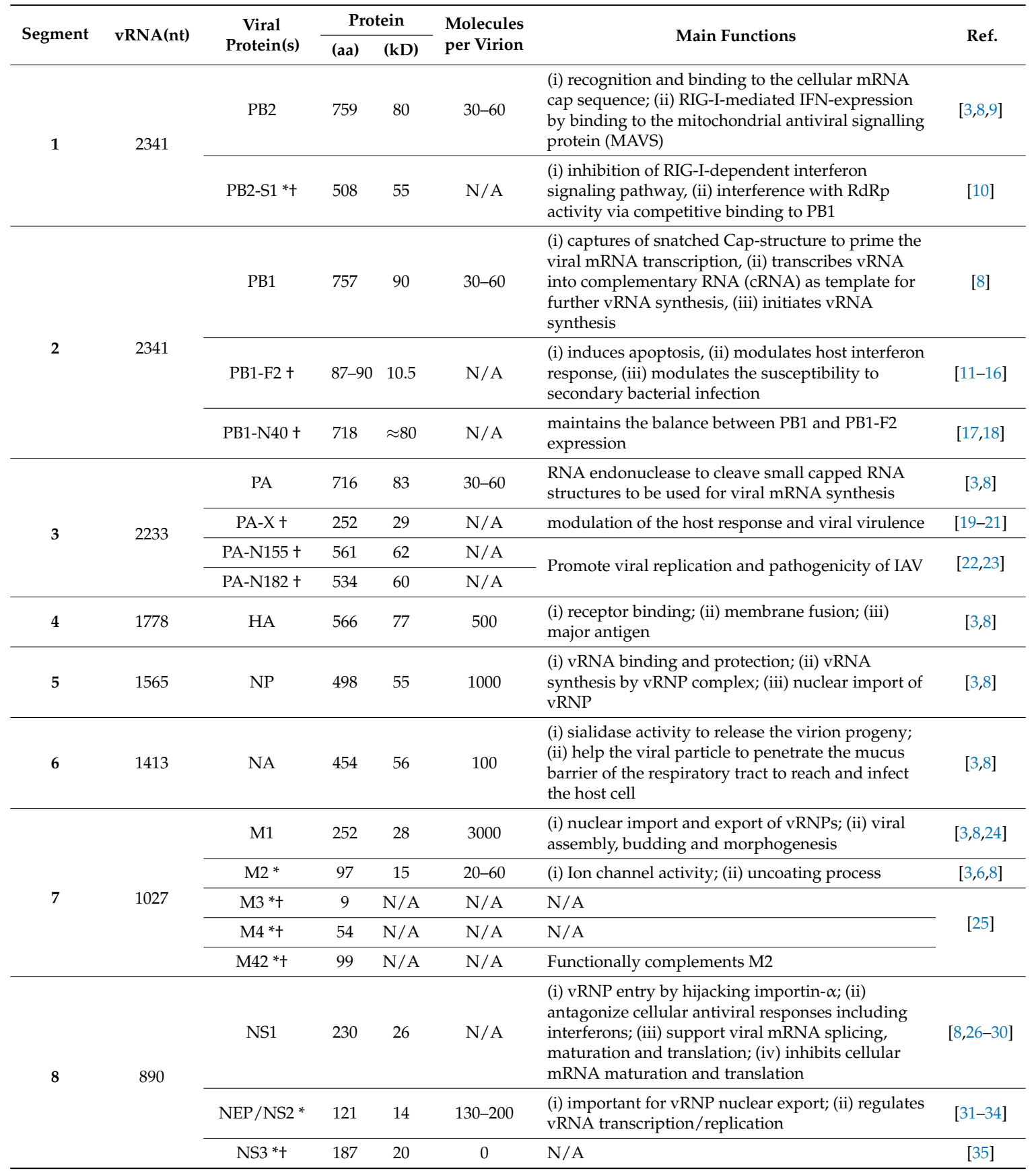

N/A means unknown; + refers to auxiliary viral proteins; * refers to viral proteins translated from spliced mRNA; aa: amino acids; kD: kilo Dalton.

As a complex genomic entity with unique structure and function among RNA viruses, the vRNP of IAVs is composed of the RNA-dependent RNA polymerase (RdRp) subunits (PB2, PB1 and PA) as a globular head linked to rod-shaped structures of the vRNAs folded on the NP protein. A breakthrough technology that allowed detailed comprehension of the vRNP structure/function, to deduce the mechanisms of RNA replication and transcription, the intracellular trafficking of the viral genome, selective packaging of the vRNPs and viral gene reassortment, was the development of the in vitro reconstitution of recombinant $v$ RNPs that represent efficient replicons. This gave also rise to the development of minigenome assays and different reverse genetic systems for IAV to study the impact 
of specific adaptive genetic changes and viral segments reassortment of zoonotic potential [36-38] (Figure 2).

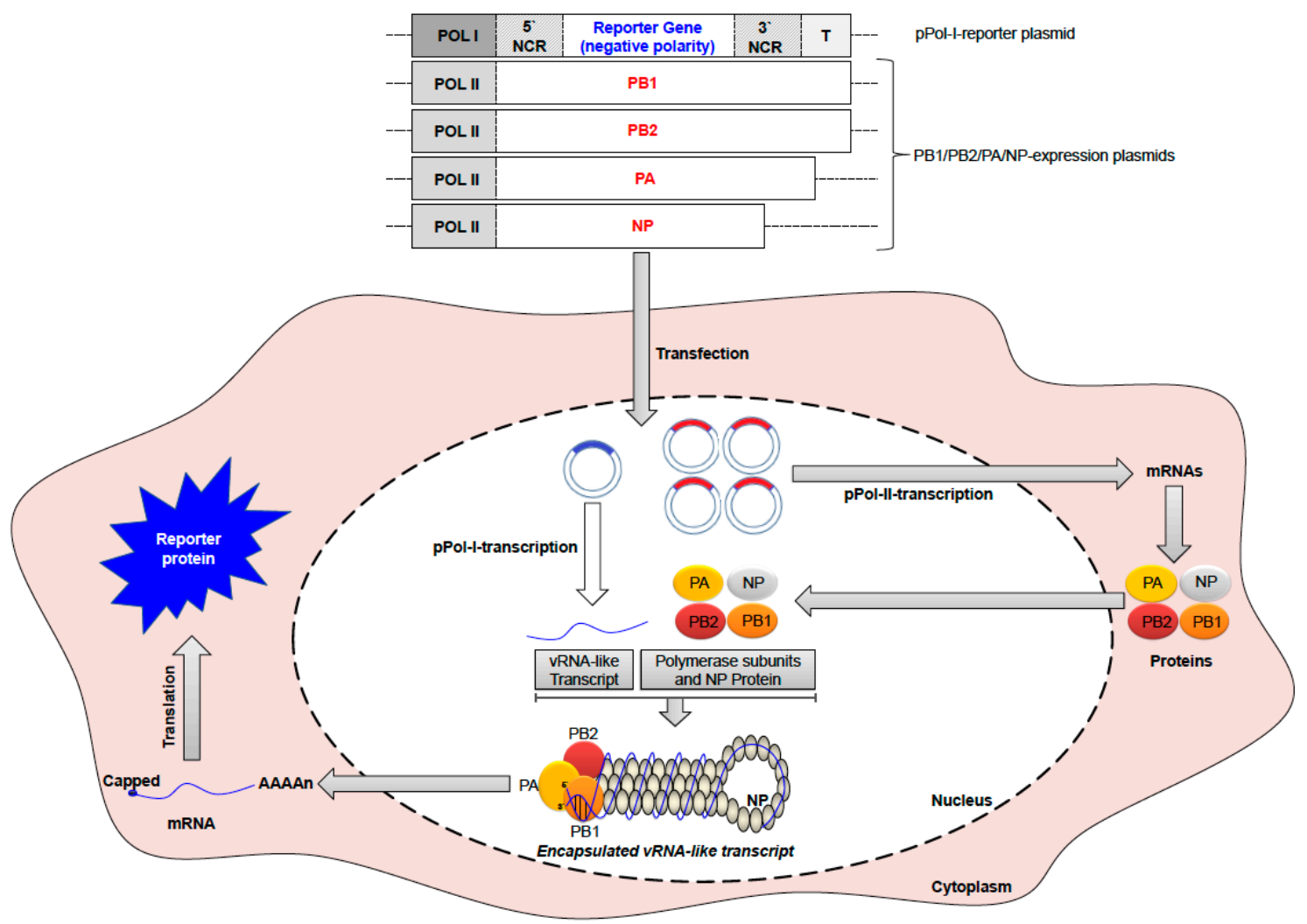

Figure 2. Overview of minigenome assay for IAV. The DNA of four expression plasmids, encoding the PB1, PB2, PA, and NP of IAV under control of polymerase II promoter (Pol-II), are co-transfected into host cell with reporter plasmid, which is carrying the ORF of the reporter gene (e.g., Luciferase, CAT, GFP) in a negative polarity and flanked by the NCRs of an IAV segment. Transcription is controlled by a Pol-I promoter (Pol-I) and a Pol-I terminator (T) to express a specific vRNA-like Pol-I-transcript of the reporter gene. The expression of the viral proteins together with the vRNA-like reporter gene transcript results in the in vitro reconstitution of RNP complexes. The RNP complexes generate the corresponding mRNA, which is then translated into the reporter protein of unique enzymatic, fluorescent or chemiluminescence activity. The represented regions in plasmid constructs are not drawn to scale.

\section{Classification of Influenza A Viruses (IAVs)}

Unlike influenza B, C, and D viruses, IAV are subtyped according to the antigenicity of the surface glycoproteins into $16 \mathrm{HA}$ - and 9 NA-subtypes. Except for bat-origin influenza-like viruses H17N10 and H18N11, all IAV subtypes were isolated initially from avian hosts (Table 2) [39-44].

\subsection{Human versus Avian IAVs}

Humans are susceptible to infection with influenza A, B, and C viruses. A limited number of IAV subtypes are circulating in humans such as the H1N1 and H3N2 subtypes leading to seasonal infections or occasional pandemics [45-48]. Other IAV subtypes can occasionally cross the species barrier from birds to mammals/humans such as H5N1, H5N6, H6N1, H7N2, H7N3, H7N4, H7N7, H7N9, H9N2, H10N7, and H10N8, causing sporadic infections and/or fatalities [49-55]. However, almost all subtypes of IAV (except H18N11 and H17N10) are classified as avian influenza viruses (AIV). Aquatic birds are the main natural reservoir of AIV [43,56]. 


\subsection{Highly versus Low Pathogenic Avian Influenza Viruses (HPAIV vs. LPAIV)}

AIV are typed according to their pathogenicity in chickens into low pathogenic (LP) and highly pathogenic (HP) strains. LPAIVs are maintained in wild aquatic birds almost without developing severe clinical signs of the disease. The clinical signs in domestic poultry induced by LPAIVs include a body weight reduction and/or a slight drop in egg production in layers poultry [57]. In contrast to LPAIV, the HPAIV phenotype is restricted to $\mathrm{H} 5 \mathrm{Nx}, \mathrm{H} 7 \mathrm{Nx}$, and $\mathrm{H} 9 \mathrm{~N} 2$ subtypes that carry a multibasic cleavage site in their HA protein [58,59] and cause up to $100 \%$ mortality in several bird species $[57,60,61]$. Until the mid-1950s, all HPAIVs were characterized as H7-subtypes, while, in 1959, the first outbreak with HPAIV H5N1 in chickens was reported [62]. Except for the fatal outbreak in terns caused by HPAIV H5N3 in South Africa, the HPAIV outbreaks were only reported in flocks of domestic birds until 2002 [63]. Since that time, HPAIVs were frequently reported to cause fatal outbreaks in wild aquatic and terrestrial birds [64-67].

Table 2. Host range of different hemagglutinin (H1-H18) and neuraminidase (N1-N9) subtypes [43,44,54,68-70].

\begin{tabular}{|c|c|c|c|c|c|c|c|c|}
\hline $\begin{array}{c}\text { HA- } \\
\text { Subtype }\end{array}$ & $\begin{array}{c}\text { NA- } \\
\text { Subtype }\end{array}$ & Human & Swine & Equine & $\begin{array}{c}\text { Domestic } \\
\text { Poultry }\end{array}$ & $\begin{array}{l}\text { Waterfowl } \\
\text { Shorebirds }\end{array}$ & $\begin{array}{l}\text { Sea Mammals } \\
\text { (Seal/Whale) }\end{array}$ & Bat \\
\hline H1 & N1 & H1/N1 & $\mathrm{H} 1 / \mathrm{N} 1$ & & H1/N1 & $\mathrm{H} 1 / \mathrm{N} 1$ & H1 & \\
\hline $\mathrm{H} 2$ & N2 & $\mathrm{H} 2 / \mathrm{N} 2$ & H2/N2 & & $\mathrm{H} 2 / \mathrm{N} 2$ & H2/N2 & N2 & \\
\hline H3 & N3 & H3/N3 & H3 & H3 & $\mathrm{H} 3 / \mathrm{N} 3$ & $\mathrm{H} 3 / \mathrm{N} 3$ & $\mathrm{H} 3 / \mathrm{N} 3$ & \\
\hline $\mathrm{H} 4$ & N4 & N4 & $\mathrm{H} 4$ & & $\mathrm{H} 4 / \mathrm{N} 4$ & $\mathrm{H} 4 / \mathrm{N} 4$ & $\mathrm{H} 4$ & \\
\hline H5 & N5 & H5 & H5 & & H5/N5 & H5/N5 & N5 & \\
\hline H6 & N6 & H6/N6 & H6/N6 & & $\mathrm{H} 6 / \mathrm{N} 6$ & H6/N6 & & \\
\hline H7 & N7 & H7/N7 & & H7/N7 & $\mathrm{H} 7 / \mathrm{N} 7$ & H7/N7 & H7/N7 & \\
\hline H8 & N8 & N8 & & N8 & $\mathrm{H} 8 / \mathrm{N} 8$ & H8/N8 & & \\
\hline H9 & H9 & H9/H9 & H9 & & H9/N9 & H9/N9 & N9 & \\
\hline $\mathrm{H} 10$ & N10 & H10 & & & H10 & H10 & $\mathrm{H} 10$ & N10 \\
\hline H11 & N11 & & & & H11 & H11 & & N11 \\
\hline H12 & & & & & H12 & H12 & & \\
\hline H13 & & & & & H13 & H13 & H13 & \\
\hline H14 & & & & & H14 & H14 & & \\
\hline H15 & & & & & H15 & H15 & & \\
\hline H16 & & & & & H16 & H16 & & \\
\hline H17 & & & & & & & & H17 \\
\hline H18 & & & & & & & & H18 \\
\hline
\end{tabular}

\section{Evolution and Epidemiology of IAV}

IAV evolve mainly by two mechanisms: (1) through accumulation of point mutations due to the lack of a proof-reading function of the RdRp, leading to aa changes (referred to as antigenic drift) (Figure 3A) and (2) by reassortment of viral segments from different IAV during co-infection (referred to as antigenic shift) (Figure 3B). Interestingly, the point mutation rate is higher in human than in avian IAV [71]. In addition, a slower evolution rate has been observed in IAV isolated from wild aquatic birds compared with those from terrestrial poultry, swine or humans. This is probably due to adaptation of IAV to new hosts, while genetic stasis is maintained in its natural reservoir [42,43,72]. Additionally, reassortment was only reported to take place within each influenza virus genus (A, B, and $C$ ), but has not been observed among different genera [73]. Genetic reassortment and antigenic drift, resulted in 5 documented influenza pandemics since 1900 and in annually repeated seasonal epidemics, respectively [74]. 
(A)

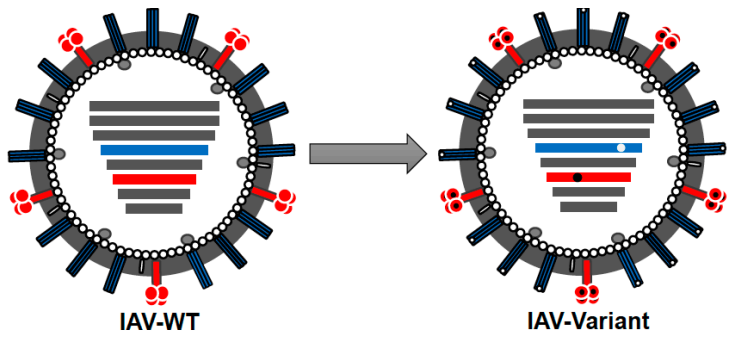

(B)

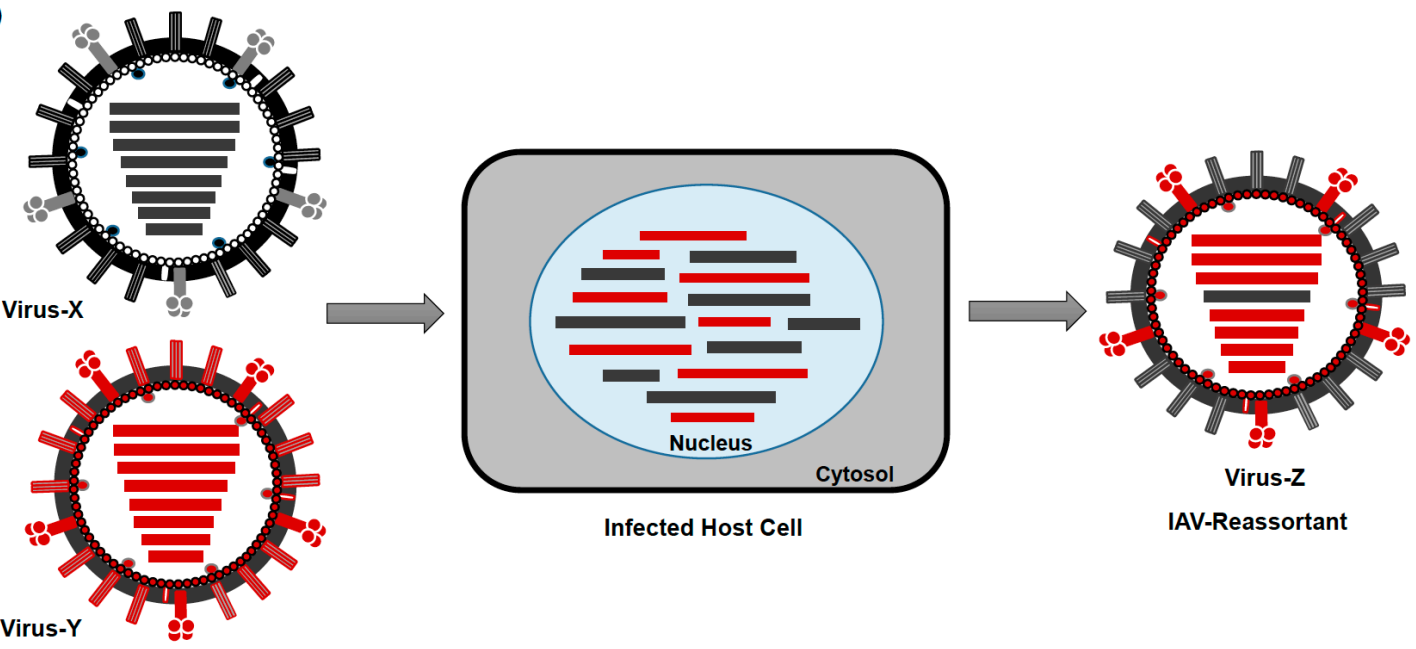

Figure 3. Evolution mechanisms of IAV. (A) Antigenic Drift: Gradual accumulation of mutations in the genome of IAVs leads to emergence of new virus variants. Mutations in the HA (blue) and NA (red) can affect the antigenic epitopes leading to antigenically new variants. (B) Antigenic Shift: The exchange/reassortment of genetic segments between two or more invading IAVs in a host cell can lead to emergence of (antigenically) distinct new subtype(s).

Unlike epidemics, pandemics (Figure 4) can spread over a wide geographic area in relatively short time resulting in thousands or even millions of fatal infections. The notorious Spanish influenza (H1N1) led to the most dramatic pandemic of the last century, globally killing more than 25 million people in 25 weeks between 1918/1919. Subsequently, a new pandemic strain-Asian Flu (H2N2)—a reassortant of 1918/H1N1 and the HA/NA/PB1 segments of an AIV, emerged in China in 1957 leading to at least one million fatalities. In 1968, the pandemic Hong Kong Flu (H3N2), a reassortant of the 1957/H2N2 and HA/PB1 segments from another avian IAV, emerged to replace the older H2N2 strain and led to about one million deaths [42]. In 1977, Russian influenza, which is thought to be caused by a re-emerged H1N1 virus, spread worldwide, leading to severe infections in humans with a $50 \%$ fatality rate among school-aged children [75]. In 2009, a reassortant H1N1 (H1N1pdm09) virus with a unique genome constellation generated in swine led to the first pandemic of the current century, known as "Swine Flu." The PB2 and PA segments were derived from a North American AIV, the PB1 segment from a human H3N2 virus, the NA and M segments from an Eurasian avian-like swine virus, and the HA, NP, NS segments from the H1N1-type classical swine virus [76,77]. Unlike H2N2, the H3N2 and H1N1 viruses are still circulating in the human population together with IBV strains [78]. In March 2018, a seasonal reassortant IAV-subtype H1N2 with genome segments from seasonal H1N1pdm09 (HA and NS) and H3N2 (PB2, PB1, PA, NP, NA and M) was identified in a 19-months-old patient with influenza-like illness in the Netherlands [79]. However, epidemiological and virological investigation did not reveal additional human infections with this H1N2-subtype in the same region [79]. 


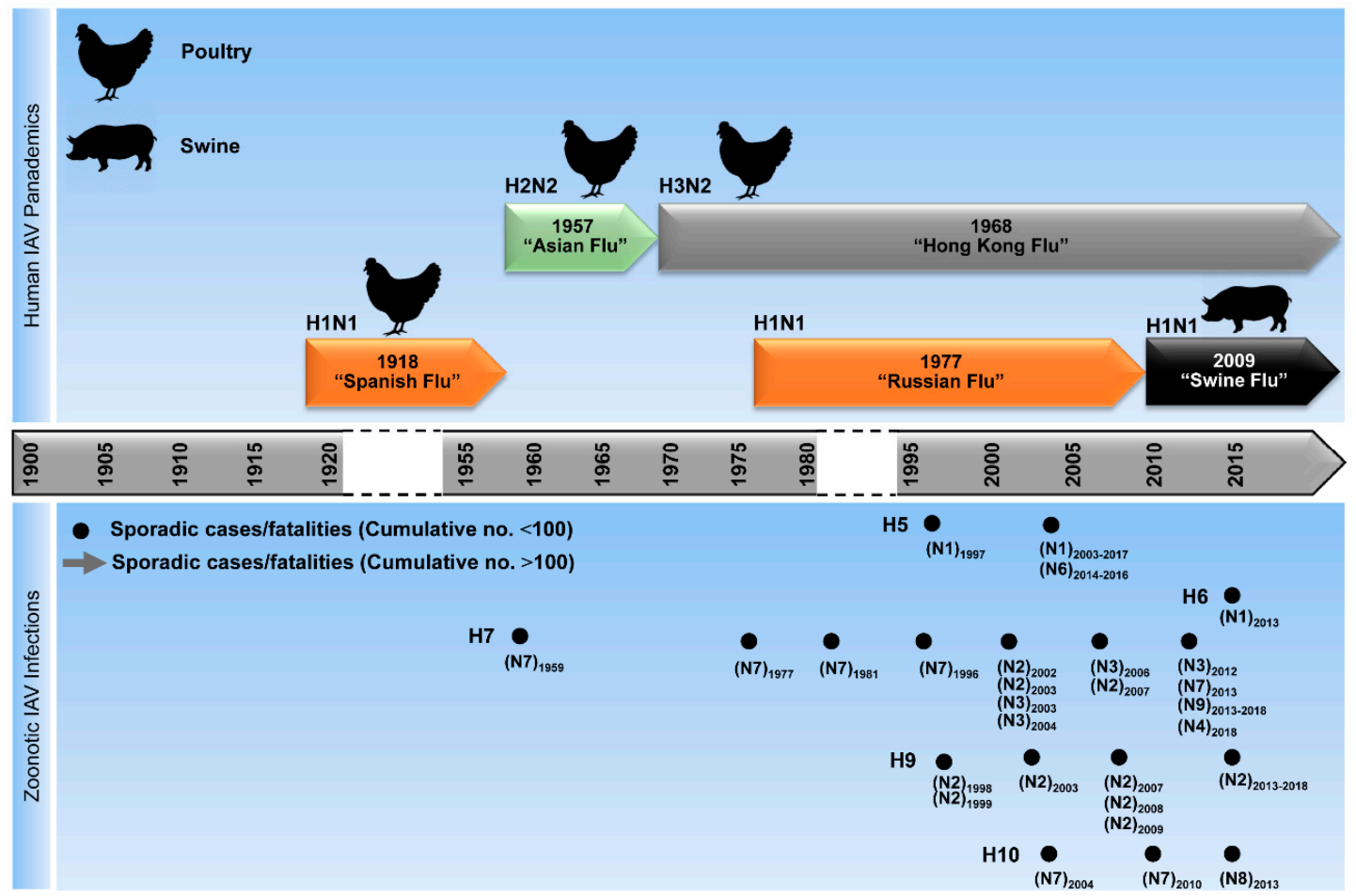

Figure 4. Timeline showing influenza pandemics and epidemics caused by IAVs. The "Spanish Flu" of 1918 was the most devastating influenza pandemic in the 20th century and was likely caused by a zoonotic transmission of an H1N1-type IAV from poultry to humans. This strain disappeared in 1957 when the influenza virus A/H2N2, a reassortant of the H1N1 virus and other avian IAVs, appeared and led to the second influenza pandemic — the "Asian Flu." In 1968, H3N2, a novel reassortant strain between the H2N2-type and an H3-type virus, displaced the H2N2 strain in the human population and led to the "Hong Kong Flu" — the third influenza pandemic. In 1977 the H1N1 strain reemerged, resulting in the "Russian Flu". In 2009, a new H1N1 reassortant was transmitted from swine to humans leading to the first pandemic of the 21st century - the "Swine Flu." In parallel, different avian influenza A virus strains (H5-, H6-, H7-, H9-, and H10-types) have occasionally crossed the host barriers causing mild-to-fatal infections in humans.

Furthermore, AIVs circulated in different bird species for decades and caused dramatic outbreaks [60]. In 1997, a lethal AIV (type H5N1) was transmitted from chickens to humans, leading to six fatalities out of 18 infected individuals in Hong Kong [51,80,81]. In a second distribution wave in 2003, it was then disseminated via migratory birds throughout Asia and introduced into poultry in Europe, the Middle East, and Africa [82,83]. In parallel, other AIVs, such as H7N2-, H7N3-, H7N7-, H9N2-, and H10N7-type AIV have been occasionally reported to cause mild-to-fatal, sporadic infections in humans in different geographical localities [44,84-87]. Since 2013, new reassortant AIVs (e.g., H5N6, H6N1, H7N4, H7N7, H7N9, H9N2, H10N8) have crossed the species barrier to infect humans inducing asymptomatic to fatal infections (Figure 5) $[49,50,52,55,88,89]$. Remarkably, breaking the host barrier was mostly supported by the acquisition of gene segment(s) from other co-circulating AIVs, especially H9N2 [90]. Here we provide a brief description of the genesis of the recent AIVs, which crossed the animal/human interface. 


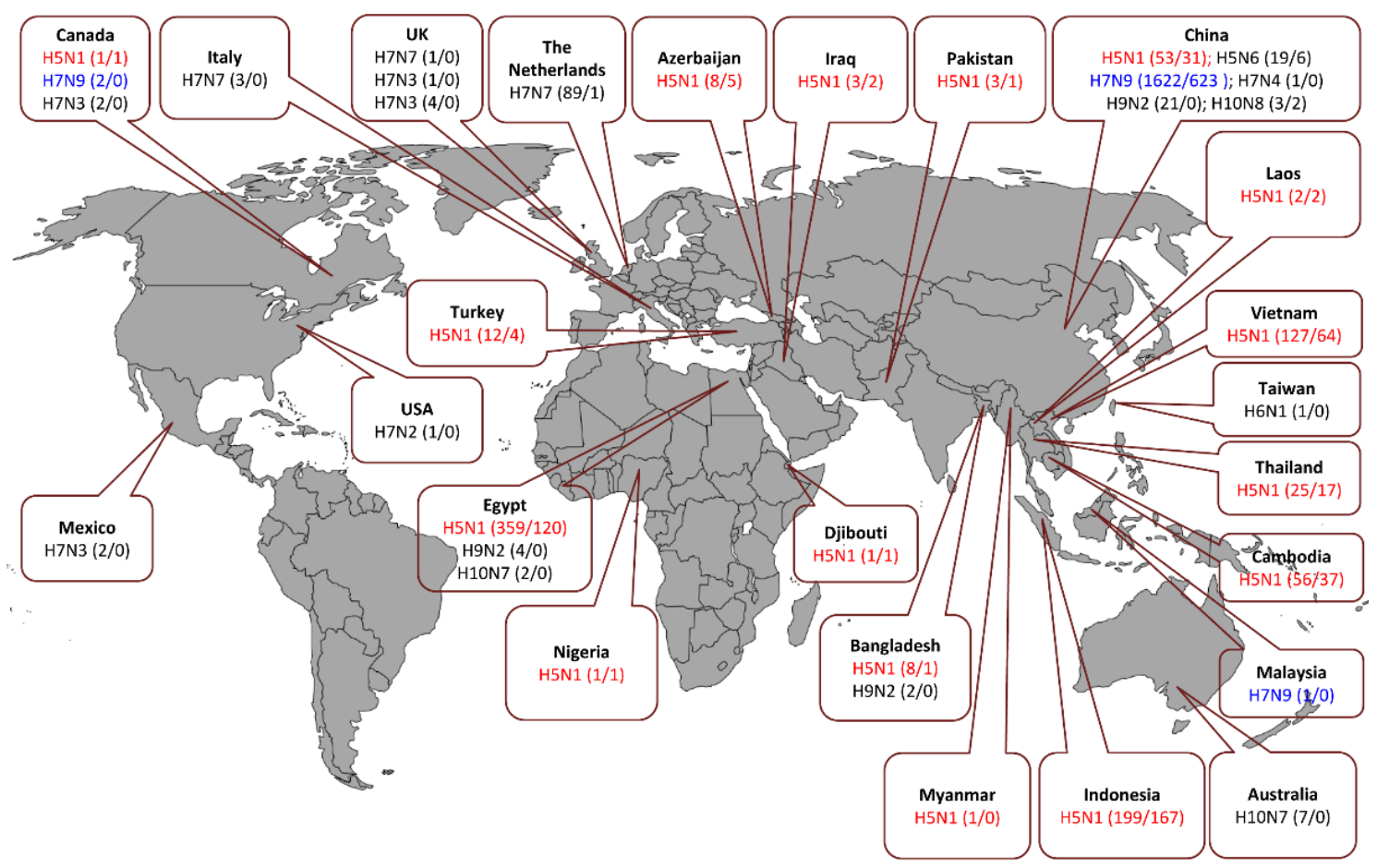

Figure 5. Documented human cases and fatalities caused by zoonotic AIVs. Zoonotic events by $\mathrm{H} 5 \mathrm{Nx}, \mathrm{H} 6 \mathrm{~N} 1, \mathrm{H} 7 \mathrm{Nx}, \mathrm{H} 9 \mathrm{~N} 2$, and $\mathrm{H} 10 \mathrm{Nx}$ viruses were reported in the indicated countries. In brackets the number of confirmed cases against the number of fatalities until July 2018 countries are indicated [44,91-93]. Compared to other human isolates of AIVs (black), H5N1 (red), and H7N9 (blue) demonstrated increased zoonotic potential.

\subsection{H5N1 (HPAIV)}

As already noted, the HPAIV H5N1 strain was documented for the first time to have crossed the animal-to-human barrier in 1997, causing zoonotic fatal infections. By genetic analysis of the 1997 HPAIV H5N1, it was revealed that the six internal protein-encoding segments (PB2, PB1, PA, NP, M, NS) were derived from co-circulating avian H9N2 viruses [94,95] (Figure 6). The presence of the same set of segments in two human H9N2 isolates in 1999 indicates an involvement of these segments in interspecies transmission [94]. Continuous evolution of the HPAIV H5N1 viruses that have undergone further multiple reassortments with other AIVs since 2003 was reported in several studies [96-98].

From January 2003 to May 2018, 860 human HPAIV H5N1 infections (including 454 fatalities) were reported worldwide. As evidenced by the low incidence rate compared to the H7N9 infections (see Section 3.7, H7N9), the risk of poultry-to-human transmission of HPAIV H5N1 strains is relatively low, but the case fatality rate (53\%) is high [91]. Due to their rapid evolution and genetic diversity, HPAIV H5N1 viruses were classified into first order clades (designated clades 0 to 9), which are further diversified into second, third or fourth order clades (e.g., 2.3, 2.3.4, 2.3.4.4) and sub-clades (e.g., 2.3.4.4b) according to their HA segment sequence [99-101] and genotypes [102].

In 2003, clade 1 strains were first detected in northern Vietnam. Recently, clade 1 viruses are phylogenetically designated as clades 1.1 .1 and 1.1.2 [100,103]. In 2005, clade 2.2 viruses were transmitted by wild birds from Qinghai Lake in western China to other Asian, European and African countries. Clade 2.2 has disappeared worldwide, except for Egypt, where in 2008 the virus became endemic in poultry and evolved into two distinct clades (e.g., 2.2.1.1 and 2.2.1.2) [103,104]. From March 2006 to May 2018, Egypt has reported a total of 359 cases, including 120 deaths mainly caused by these clades [91,104]. Since 2008 viruses evolved in China, Southeast Asia forming the new clade 2.3.2.1, which gained high prevalence, gradually replacing clade 1 viruses, and were also transmitted to Europe. Clade 2.3.2.1 continued its evolution resulting in new, genetically diverse sub-clades 
(2.3.2.1a, b and c) [103], which are associated with sporadic, but fatal human infections in the last few years [105-110]. Currently, clade 2.3.2.1c viruses have become dominant in poultry throughout China, Cambodia, Laos, Indonesia, and Vietnam [103]. Similar to the geographically restricted clade 2.2.1.2 in Egypt, endemic clade 2.1.3 viruses in Indonesia, recently evolved to the new clade 2.1.3.2b [103]. Furthermore, viruses of clade 2.3.2.1c have been introduced to Indonesia, representing a challenge for the implemented strategies for diagnosis and control of HPAIV H5N1 viruses in this area.

Currently, out of the more than 30 previously reported genetic clades, clades 1.1.2 (Cambodia and Vietnam), 2.1.3.2b (Indonesia), 2.2.1.2 (Egypt), 2.3.2.1c (Bangladesh, China, India, Indonesia, Korea, Nepal, and Vietnam), 2.3.4.2 (China), and 7.2 (China and Vietnam) are circulating in domestic poultry [111].

\subsection{H5N6 (HPAIV)}

In April 2014, the first fatal human infection with HPAI H5N6 was reported in China [112]. Patients acquired the infection through contact with infected poultry, particularly in live bird markets. The manifestation of the infection in humans ranged from influenza-like illness including fever and severe pneumonia to death. The genome of this strain was a combination of the HA segment from avian influenza A/H5N2 viruses (clade 2.3.4.4), the NA segment from avian influenza A/H6N6 viruses and internal protein encoding genes from avian influenza A/H5N1 viruses (clade 2.3.2.1c) [112]. To date, three different reassortants of HPAIV H5N6 crossed the species barrier and caused severe infections in human with high mortality rate [113]. The strain "reassortant A-HPAIV H5N6" represents the prototypic HPAI H5N6 strain, which led to the first fatal H5N6 infection in humans. Independently, "reassortant B-HPAIV H5N6" concurrently resulted from reassortment between H5N8 (clade 2.3.4.4), and H6N6 viruses. Subsequently, the "reassortant B-HPAIV H5N6" was subjected to a single reassortment event by which it acquired the six internal genes of a co-circulating influenza A/H9N2 strain resulting in "reassortant C-HPAI H5N6" (Figure 6) [113]. In November 2016, a human fatality was associated with the isolation of $\mathrm{H} 5 \mathrm{~N} 6$ viruses, which originated in poultry after multiple reassortment events of several AIVs, including H3N2, H5Nx, H6N2, H7N3, and/or H9N2 [114,115]. This indicates the high zoonotic potential of these H5N6 viruses. From 2014 to May 2018, a total of 19 laboratory-confirmed human H5N6 infections (including six fatalities, case fatality rate $=32 \%$ ) in China have been reported to WHO [116].

\subsection{H6N1 (LPAIV)}

Although the avian H6Nx viruses have shown the ability to productively infect and cause illness in mammalian model animals (mice and ferrets) without prior adaptation, the H6-type viruses were not detected in humans until May 2013 [117], when a human infection with LPAIV H6N1 was reported for the first time in Taiwan [118]. Coalescent-based phylogenetic analyses of the human influenza H6N1 strain showed that it was likely to be derived from different H6N1 strains and not by direct reassortment with the co-circulating AIV H5N2 [52]. Due to the high compatibility and the frequent reassortment between $\mathrm{H} 5 \mathrm{~N} 2$ and the internal genes of $\mathrm{H} 6 \mathrm{~N} 1$, there is a concern about the indirect contribution of H6N1-internal genes to trigger human infections when incorporated into the genetic backbone of American lineage influenza A/H5N2 viruses [119].

\subsection{H7N2 and H7N3 (LPAIV and HPAIV)}

First evidence of human infections with H7N2 (LPAIV) and H7N3 (LPAIV) was based on positive retrospective serologic analysis of workers involved in the poultry outbreaks in the United States (USA, Virginia) and Italy in 2002 and 2003, respectively [120]. The H7N2 (LPAIV) was then virologically reported in 2003 in an immune-compromised patient in the United States (New York, NY, USA), and later in 2007, it was detected in four human cases in the United kingdom (Wales, UK) [44]. In addition, H7N3 (HPAIV / LPAIV) and H7N3 (LPAIV) led to sporadic human infections in 2004 and 2006 in Canada (British Columbia) and the UK (Norfolk), respectively [120,121]. In 2012, two confirmed 
mild infections of humans with H7N3 (HPAIV) were detected following exposure to infected poultry in Mexico (Jalisco) [121].

\subsection{H7N4 (HPAIV)}

In February 2018, the Chinese National Health and Family Planning Commission (NHFPC) announced the first non-fatal human infection of H7N4 in Jiangsu Province. The patient was a 68-year-old woman who acquired the infection after exposure to poultry in a live bird market [54].

\subsection{H7N7 (HPAIV)}

Mild human infections with HPAIV H7N7 “conjunctivitis" was reported in 1959, 1977, and 1981 [120]. The most prominent human outbreak of HPAIV H7N7 occurred in the Netherlands in the spring of 2003 leading to 89 human cases including the first reported fatality due to HPAIV H7N7 infection $[86,120,122]$. The internal genes of this HPAIV H7N7 were of avian origin and were genetically related to the previously circulating LPAIV H7N7 in ducks in the same region in 2000 [86]. In September 2013, three poultry workers in Italy were infected with H7N7 AIV. They acquired the infection after participation in culling of poultry infected with HPAIV H7N7. The patients had conjunctivitis. Genetic analyses of all gene segments indicated high similarity to the H7N7 viruses isolated from chickens on affected farms [123]. In 2013, a previously unrecognized low pathogenic H7N7 lineage carrying the complete set of internal genes from H9N2 subtype AIV was detected in chickens in China and has the ability to infect mammals experimentally (Figure 6) [90].

\subsection{H7N9 (LPAIV)}

In 2013, zoonotic infections with LPAIV H7N9 were first reported in China [49]. The human pathogenic H7N9 is derived from multiple reassortments between AIV H7N9 (NA), H7N7 (HA), and H9N2 (internal proteins coding gene segments) in domestic ducks and chickens [90]. The virus is still maintained in poultry leading only to sporadic human infections. In February 2017, the Chinese province Guangdong reported the first human infection with the mutated trypsin-independent HPAIV H7N9 [124]. Recent studies revealed that the newly emerging HPAIV H7N9 viruses acquired the internal protein-coding genes from co-circulating H9N2 strains [125]. Despite the higher viral polymerase activity, increased replication efficiency and pathogenicity in human, no clear impact on viral transmissibility or virulence was noticed for HPAIV H7N9 [126]. From February 2013 to July 2018, there were a total of 1625 human infections (LPAIV H7N9: 1593 cases, HPAIV H7N9: 32 cases) in China, Malaysia (one case, imported from China) and Canada (two cases, imported from China) with an average of 295 cases per year. The infections caused a total of 623 fatalities ( $38 \%$ case fatality rate) $[93,116]$. Since 2013, six waves of LPAIV and HPAIV H7N9 were documented (Table 3) [92,127].

Table 3. Confirmed human infections / fatalities with LPAIV- or HPAIV H7N9 per wave.

\begin{tabular}{cccccc}
\hline Wave Number & Period & Phenotype & Cases & Fatalities & Fatality Rate \\
\hline 1 & February 2013-September 2013 & LPAIV & 134 & 45 & $34 \%$ \\
2 & October 2013-September 2014 & LPAIV & 306 & 131 & $43 \%$ \\
3 & October 2014-September 2015 & LPAIV & 219 & 102 & $47 \%$ \\
4 & October 2015-September 2016 & LPAIV & 114 & 47 & $41 \%$ \\
5 & October 2016-September 2017 & LPAIV/HPAIV & 848 & 295 & $35 \%$ \\
6 & Since October 2017 & LPAIV/HPAIV & 4 & 3 & $75 \%$ \\
\hline
\end{tabular}

As indicated, the highest number of human H7N9 infections has been reported during the fifth epidemic wave, with a geographic range expansion within Chinese provinces [128]. Despite the fact that the outbreaks of LPAIV H7N9 are continually reported in poultry, no new human infections were documented since February 2018. To date, 40 family clusters of 2-3 persons with confirmed or 
suspected infection with LPAIV and HPAIV H7N9 were reported [116], however, there is no clear evidence that H7N9 virus have evolved to sustain human-to-human transmission.

\subsection{H9N2 (LPAIV)}

Since the mid-1980s, the LPAIV H9N2 circulates extensively worldwide in poultry resulting in high genetic diversity $[129,130]$. Based on phylogenetic analysis of the HA segment sequence, H9N2 viruses are designated either as Eurasian or American lineages [95,129]. The Eurasian lineage include three genetically distinct sublineages: (1) Y280-like lineage, represented by A/duck/Hong Kong/Y280/97 (Y280-like), A/Chicken/Beijing/1/94 (BJ94-like), and A/Chicken/Hong Kong/G9/97 (G9-like); (2) G1-lineage represented by A/quail/Hong Kong/G1/97-like (G1-like), and (3) Korean lineage represented by A/Duck/Hong Kong/Y439 (Y439-like) and A/chicken/Korea/38349-p96323/96 (Korean-like) [95,131,132].

Since the mid-1990s, the BJ/94-, G9-, and G1-like H9N2 viruses are predominantly circulating in chickens and quails in China. Since 2010, the G1-like lineage demonstrated a widespread distribution and prevalence throughout Asia, the Middle East, North Africa, and Europe [130,133,134].

H9N2 viruses are predominantly isolated from domestic poultry and live-bird markets, which were proven to be risk factors for zoonotic transmission of AIVs from birds to humans [135,136]. The seroprevalence for G9- and G1-like H9N2 antibodies among occupationally exposed populations in Southern China emphasized the high incidence rate of subclinical human infections with both prevalent H9N2 lineages [137]. Moreover, in different geographical locations, H9N2 IAVs have crossed the species barrier due to their mammalian-like characteristics, causing mild to moderate infections [135,138,139]. Globally, since March 2013, a total of 27 laboratory confirmed human clinical infections were reported in three hotspots of human AIV infections ( 21 cases in China, 4 cases in Egypt, and 2 cases in Bangladesh) (Figure 4) [92]. Currently, the global concern about H9N2 viruses is associated with their ability to donate their genes to other AIV giving rise to high and low pathogenic IAVs that could cross species barriers and infect humans (Figure 6). In addition to the zoonotic H5N6, H7N9 and H10N8 AIV, the H9N2 viruses also donated their internal genes to other IAVs, such as avian H5N1 [140,141], H5N2 [136,141], H1N2, H3N2, H6N2 [141], and H6N6 [142].

\subsection{H10N7 (LPAIV)}

Although outbreaks of H10N7 are uncommon, this virus can sporadically cross the species barrier to mammals including humans. Human infections with H10N7 were occasionally reported from Egypt (2004) and Australia (2010) [143]. Recent H10N7 AIV-associated natural outbreaks in harbor seals and experimental infection of ferrets emphasize that H10N7 may possess a zoonotic potential [144-146].

\subsection{H10N8 (LPAIV)}

In late 2013, a fatal human infection with LPAIV H10N8 was identified in China [55]. Notably, the human H10N8 IAV isolate possessed genes coding for internal proteins, which were genetically related to the contemporary AIV H9N2 strains (Figure 6) [50,55], suggesting that this unique genetic constellation was established in poultry. Non-fatal human infections with H10N7 IAV were previously reported in 2004 and 2010 at other geographical localities (reviewed in [44,50]). 


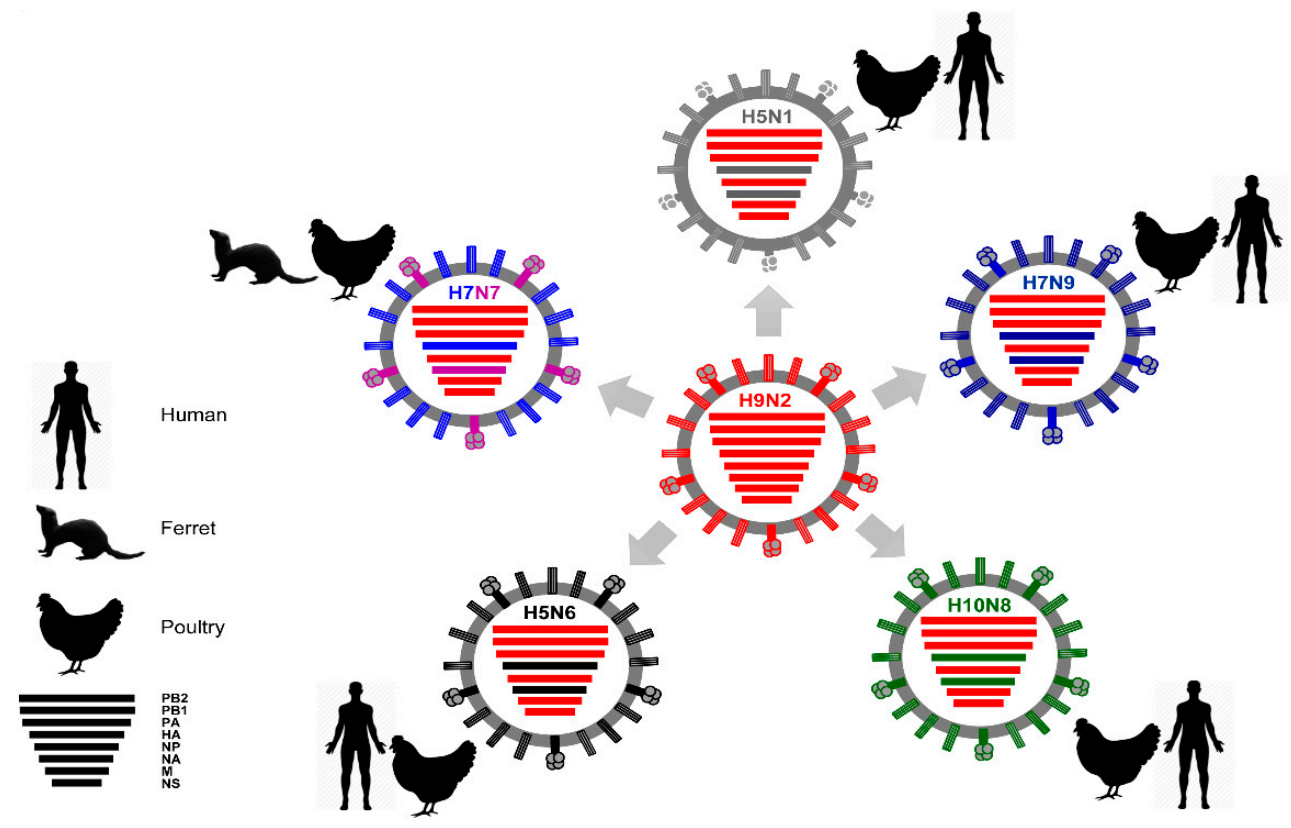

Figure 6. H9N2-type influenza A viruses donate their internal genes to other IAVs. Recent studies revealed the contribution of the internal genes of H9N2 in the genesis of various, recently evolved AIV strains with zoonotic potential $[135,138,139]$. Poultry (chicken pictogram) served as mixing hosts for emergence of these influenza reassortants, which are then transmitted naturally to humans (human pictogram), or evaluated experimentally in ferrets (ferret pictogram), leading to infections/deaths.

\section{Sources of Human Infections with Zoonotic IAV}

Although the infection of humans with zoonotic influenza viruses is less frequent than infections with seasonal influenza viruses, there is a global concern that these zoonotic viruses may acquire mutations in animals or humans that favour the efficient animal-to-human or sustained human-to-human transmission. Poultry and pigs are the major sources of human infections with IAVs. The portal of entry for human infections is mostly through the conjunctiva (e.g., rubbing the eye), nasal and mucosal membranes (e.g., inhalation of dust, droplets), or probably swimming in contaminated pools. Eating of well-cooked meat is not a source of human infections with IAVs until now [147-150].

Generally, the human infections with AIV were found to be limited to individuals with intensive direct contact with the infected animals and few numbers of family clusters without sustainable human-to-human transmission were reported [151-153]. The contact with poultry in live bird markets (LBM) is an important source of human infections with AIV in Asia (e.g., H5N1, H7N9, H9N2, H10N8). In LBM, mixing of different species of birds (chickens, ducks, geese, pigeons, etc.) from different sources (wild birds, backyards, and commercial farms) is a suitable niche for persistence and perpetuation of AIV. Therefore, the partial or complete closure of LBM and effective cleaning and disinfection were effective procedures to temporarily stop poultry-to-human infections. Moreover, backyard birds were claimed to be the main source of human infections with H5N1 and H9N2 in Egypt, where women and children were more frequently infected due to slaughtering, defeathering, evisceration, or playing with infected birds [154,155]. Interestingly, few human infections were reported due to rearing or culling of farmed animals. Several serological surveillance studies have shown that zoonotic IAV infections are more frequent in workers of poultry and pig farms [156-158]. Moreover, AIV infection of humans (e.g., hunters) through the direct contact with wild birds is an additional risk factor [159,160].

\section{Viral Determinants for Zoonotic Potential of IAV}

The pathogenicity of IAV is a complex and multigenic trait, which is affected by several viral and host factors. Nowadays, the accessibility of sequencing data from a large number of viral strains 
together with the availability of different reverse genetics (RG) approaches for IAV [37,161-163], allow a better understanding of various host range and virulence determinants of IAV. Actually, intensive circulation of AIVs in animal reservoirs results occasionally in the emergence of genetic traits, which are at least sufficient to enable the virus to cross the animal-to-human transmission barrier. Furthermore, genetic changes improving viral fitness of zoonotic AIVs could been gained in the new (human) host [164]. Whether such genetic and phenotypic changes are part of the zoonotic potential needed for transmission or are part of the adaptation in the human host needs to be analyzed. For instance, different well-studied adaptive genetic changes in human AIV isolates (e.g., Q591K, E627K or D701N) were also detected in avian or other intermediate hosts, but to lesser extent [111,165-167]. To better assess the pandemic risk-potential of AIVs, a profound understanding for the implications of these (adaptive) changes on viral characteristics seems to be of great importance.

\subsection{The Viral Polymerase Complex and NP Protein}

Amino acid (aa) substitutions in the subunits of the RdRp have been reported to alter the replication, pathogenicity and host range of IAV in mammals and poultry [168]. The presence of specific aa at several positions in the PB2 subunit (627K, 526R/627K, 590S/591R, 701N, 253N/591K, 253N/291K, $158 \mathrm{G}$, and 271A), were associated with an increase in viral polymerase activity and contributed to increased virus replication and pathogenicity in mammals [164,169-171]. Remarkably, a glutamic acid replacement at position 627 with lysine $(\mathrm{E} 627 \mathrm{~K})$ in PB2 is an important host range determinant, which enhances efficient replication, transmissibility and pathogenicity of AIV in mammals [172,173]. One study reported the importance of position 627 as a determinant for the temperature sensitivity of viral RdRp and therefore for viral genome replication [174]. In general, human IAV prefer a temperature of approximately $33{ }^{\circ} \mathrm{C}$ to replicate in the upper respiratory tract (URT), whereas AIV replicate best at $41{ }^{\circ} \mathrm{C}$ in the intestinal tract. Contrary to AIV with 627E in the PB2, AIVs carrying a E627K substitution efficiently replicate at $33{ }^{\circ} \mathrm{C}$ in URT of mammals [175]. However, absence of $627 \mathrm{~K}$ can be compensated by $701 \mathrm{~N}$ to result in higher replication, transmissibility and virulence of AIV in mammals [176]. Both, the $627 \mathrm{~K}$ and $701 \mathrm{~N}$ seem to be human signature markers that have been found in most human isolates of H7N9 causing human infections and fatalities in China in 2013 [90]. Of note, the pandemic $2009 \mathrm{H} 1 \mathrm{~N} 1$ virus is missing $627 \mathrm{~K}$ and $701 \mathrm{~N}$ without significant impact on virus replication and transmission in mammals [169,177], which is likely due to two compensatory residues, 590S and 591R [169].

In PB1, most avian IAV carry asparagine at position 375, whereas most human IAV including the pandemic 1918-H1N1, 1975-H2N2 and 1968-H3N2, contain a serine at this position [178]. Therefore, the aa residue 375 in PB1 might be critical for adaptation and virulence of avian IAV in mammals as a new species [178,179]. Retrospective analysis of the 1957 and 1968 pandemic strains suggested that avian PB1 in the genetic background of human IAV could promote efficient replication, transmission and virulence in mammals [180-182]. In addition, PB1-F2 contributes to higher pathogenicity of avian IAV in mammals and to bacterial secondary infection [13-15]. Unlike the truncated non-functional PB1-F2 protein in pandemic 2009 H1N1 viruses, PB1-F2 is suggested to exert an important role in the pathogenicity of the 1918, 1957 and 1968 pandemic strains as well as the HPAIV H5N1 viruses [15,183]. In PB1-F2, 66S increased the replication and virulence of IAV in mice and antagonized virus-induced cellular response. Interestingly, a S66N substitution attenuated the H5N1 and 1918/H1N1 viruses [184].

In the PA protein, 97I was shown to enhance the virulence of influenza virus A/Aquatic bird/Korea/W81/05 (H5N2) in mice rather than in chicken and to promote efficient replication in vitro in mammalian rather than avian cell lines [185]. In addition, specific PA residues (70V, 85I, 186S, 224S, 336M, 353R, 400P, 423M 476V, 552S and 630V) were shown to improve the viral polymerase activity of different IAVs in vitro and enhance virus replication and pathogenicity in mammals [164,186-188]. However, the PA-X protein was shown to rather act as a negative regulator of pathogenicity of 1918 H1N1 and HPAIV H5N1 in mice and avian host species, respectively [19,20,189]. The loss of PA-X expression (PA-X-null) improved viral replication, increased cell-death and host innate responses, 
and thereby virulence in mice and avian species $[19,20,189]$. To summarize, the PA-X modulates IAV virulence by impairing viral and host mRNA expression, thereby affecting virus propagation and host innate immune response.

Several studies have indicated an important role of the NP protein in viral replication and pathogenicity. It is now known that the cellular antiviral-acting Mx1 (mouse) or its human ortholog MxA interact with the viral NP and thereby inhibit IAV replication $[190,191]$. Therefore, the sensitivity of IAV to mammalian MxA is affected by the nature of the viral NP protein (e.g., avian strains of IAV are typically more sensitive to MxA than human strains) [192,193]. IAVs escape from MxA restriction by acquiring specific aa substitutions in the NP [194-196]. A novel deep mutational scanning approach identified several different sites in the viral NP that either increase the sensitivity or the resistance to MxA [197].

The classical nuclear import of vRNP is primarily regulated by adaptor importin- $\alpha$ proteins, which subsequently link the nuclear localization signals (NLSs) of imported vRNP molecules to importin- $\beta$ and in turn mediate their nuclear localization $[198,199]$. The NP functions as a mediator between IAV-vRNP and the host cell karyopherins "importin- $\alpha$." The IAV-NP carries two main nuclear localization sequences (NLS). NLS1 ranges from aa positions 1-13 and NLS2 from aa positions 198-216 [200,201]. Similarly, importin- $\alpha$ interacts to different NLSs on viral polymerase subunits to mediate the nuclear import of vRNP such as NLS at aa residues 449-495 and 738-755 of PB2 [202], NLS at aa residues 187-211 of PB1 [203] and NLS at aa residues 124-139, E154, 186-247 of PA [204]. Interestingly, 319K (NP), 701N (PB2), and 627K (PB2) are important to adapt the binding of vRNP from influenza virus of avian origin to mammalian importin- $\alpha 7$ isoform [205-208]. However, IAVs with the avian signatures (627E and 701D) depend primarily on importin- $\alpha 3$ [207,208]. This switch in the usage of different importin- $\alpha$ isoforms from $\alpha 3$ to $\alpha 7$ following the acquisition of adaptive aa residues in NP and PB2 is crucial for efficient viral replication and higher polymerase activity in mammalian cells [207].

\subsection{Viral Surface Glycoproteins (HA and NA)}

The fourth segment of the IAV genome encodes for the hemagglutinin (HA), the major trimeric surface glycoprotein. It is synthesized as a single polypeptide precursor (HA0). To activate the HA fusion peptide that mediates fusion between the viral envelope and the host cell membrane, HA0 needs to be proteolytically cleaved into the two subunits, HA1 and HA2, that are held together via a disulphide bond $[3,209,210]$.

The HA plays a key role in the replication and adaptation of IAV to new hosts [211] because it is responsible for the receptor binding of IAV to the host cell membrane. The affinity of HA to specific sialic acid (SA) residues is a main determinant of host range. AIV are known to preferentially attach to sialic acid bound to galactose via an $\alpha-2,3$-linkage ( $\alpha 2,3-S A)$, which is predominant in the intestinal tract of birds [212,213], human lower respiratory tract (LRT, alveoli and bronchiolar cells junctioning bronchiole and alveoli) and conjunctival cells [214], whereas human IAVs prefer to bind to SA bound to galactose via an $\alpha 2,6$-linkage ( $\alpha 2,6-\mathrm{SA})$, which is predominant in the human URT including epithelial cells lining nasal cavity, paranasal sinuses, pharynx, larynx, trachea, and bronchi [214,215]. Importantly, both $\alpha 2,3-$ SA and $\alpha 2,6-S A$ have been detected in the URT of swine, as well as in quails giving rise to efficient replication of IAVs with affinity to human- and avian-type SA receptors [216,217].

The receptor binding residues of IAV are located in the HA head domain [218]. Several point mutations in the HA alter the SA receptor specificity, antigenicity, host range, replication efficiency and pathogenicity [219-221]. Moreover, cleavage of HA0 into the HA1 and HA2 subunits is needed to permit fusion of the viral envelope with the host endosomal membrane during virus entry to allow the viral genome to enter the cytoplasm. Thus, the distribution of HA-activating proteases in host cells is a major determinant for virus tropism and pathogenicity [61]. The cleavage site in the HA of HPAIVs (H5- and H7-subtypes) is composed of multiple basic aa residues. It can be cut by the ubiquitously expressed proprotein convertase "furin" and furin-like proteases, resulting in severe systemic infection 
in poultry and mammals [222,223]. Conversely, the HA0 proteins of LPAIVs possess a monobasic arginine $(\mathrm{R})$ residue at their cleavage site and are only activated by extracellular proteases including tryptase Clara and bacterial proteases [224,225], which are restricted to respiratory and intestinal cells, only allowing localized infection [226].

To date, the molecular determinants of efficient replication, transmission and virulence for the seasonal IAV infection in mammals have been intensively studied. Several aa substitutions were found to be connected to changes in the receptor preference of HA in subtype specific manner such as N154S, N182K, Q192R, Q222L, S223N, G224S, Q226L, S227N, L129V + A134V, G139R + N182K, Q192R + S223N, Q222L + G224S (H5-subtype), E190D, D22G (H1-subtype), G225D (H1- and H9-subtypes), and G228S (H2-, H3-, H4-, H5-, and H9-subtypes) [164]. For instance, substitutions E190D and D225G were identified to change the binding preference of H1N1-HA toward human-like receptors leading to increased disease severity [227,228]. Otherwise, Q226L and G228S in the receptor binding domain of the H2- and H3-HA seem to be associated with increased affinity toward human-like receptors [228].

Furthermore, airborne transmission of AIV among humans is of special concern. In 2012, Imai et al. have shown that the introduction of 4 mutations (N158D/N224K/Q226L/T318I) into H5-HA via serial-passaging of the HPAIV H5N1 in ferrets changed the receptor binding preference towards $\alpha 2,6-S A$ and enabled airborne virus transmission between ferrets [229]. Nevertheless, in a another study also concerning the adaptation of HPAIV H5N1 in ferrets, similar but not identical substitutions were found, leading to enhanced $\alpha 2,6-$ SA binding enabling airborne virus transmission between ferrets [230]. Interestingly, serial passaging of an HPAIV H7N1 in ferrets also resulted in an airborne transmissible variant, with only one aa change in the stalk region of HA, but with four additional mutations in the internal proteins (PB2; NP, M1) [231].

Consistently, Q226L, located in the HA receptor binding domain, contributed to the adaptation of a H10N7 AIV to seals/mammals by improving a binding affinity to the human-like $\alpha 2,6-S A$ receptor [146]. Recently, using a novel phylogenetic algorithm, Schmier et al. have predicted and experimentally confirmed the impact of three mutations (K153D, S223N and G272S) in the viral HA gene of Egyptian H5N1 AIV strains that are likely to play a critical role in changing the host cell receptor binding affinity towards mammals [232].

The neuraminidase (NA), encoded by the 6th segment of the IAV genome, forms a tetrameric spike protein with enzymatic activity. Since NA mediates the enzymatic removal of SA from the surface of infected host cells (Table 1), a balance between the strength of HA receptor-binding activity and the NA receptor-destroying activity is important for optimal infection, transmission and host adaptation of IAV [233,234]. Before its transmission to humans causing the Asian flu pandemic in 1957, the H2N2 virus possessed an NA with a preference to release progeny virions attached to avian $\alpha 2,3-\mathrm{SA}$, whereas the HA of this virus already preferred mammalian $\alpha 2,6-\mathrm{SA}$ receptors. It is assumed that this N2-NA gradually adapted in the human population, infected by the progenitor of the "Asian flu" virus, and acquired the specificity to cleave human-type receptors [235]. The aa substitution I275V in the N2-NA was also shown to increase $\alpha 2,6-S A$ receptor substrate specificity [236]. Furthermore, several studies have shown that specific deletions in the NA stalk domain-short-stalk NA-increase the virulence of AIVs in mice and poultry [237-240]. Nevertheless, short-stalk NA limits the transmission of pandemic H1N1 virus in ferrets [241].

\subsection{Non-Structural Protein 1 (NS1)}

The non-structural protein 1 (NS1) is small, multifunctional protein (mostly 230 aa/26 kDa) that is encoded by the eighth vRNA segment and translated from the unspliced viral mRNA of the NS segment. The NS1 protein exerts different activities in infected cells to promote efficient viral replication and virulence. NS1 interferes with type I IFN production as well as with IFN-inducing factors. In addition, it plays a positive regulatory role in RdRp activity and the nuclear export and translation of viral mRNAs [26,27,242]. In contrast, NS1 negatively regulates cellular pre-mRNA maturation and nuclear export, leading to preferred expression of viral genes [243]. Thereby, NS1 plays 
an important role as a regulator of viral replication, pathogenicity and host range through different protein-protein interactions [30,244-246]. For instance, by direct activation of viral mRNA translation through interactions with proteins involved in mRNA transport and translation (NXF1/TAP, Staufen, eIF4GI, and PABPI), NS1 potentiates viral replication [26,247]. Moreover, the ability of NS1 to antagonize the virus-induced antiviral response promotes viral replication [30]. Therefore, genetic drift by aa deletions, mutations and truncations that abolish or potentiate the ability of the NS1 to block the IFN production, can affect the overall yield and the pathogenicity of propagated virus [248]. For example, F103L and M106I substitutions in the NS1 increased virus replication and virulence of AIV in mammals [249]. In the NS1 of H5N1 viruses, the D92E substitution or the deletion of five aa residues (80-84) increased virulence in avian and mammalian animal models [250-252]. However, another naturally occurring five aa deletion (residues 191-195) in the NS1 of swine H5N1 viruses contributed to an inefficient ability of NS1 to control the IFN response and thereby reduced pathogenicity of these viruses in mice and chickens [253], as this deletion disrupted the essential binding of the NS1 to the splicing and polyadenylation factor CPSF-30 [253]. Furthermore, recent studies have shown that NS1-binding to CPSF-30 is also impaired by specific aa residues (108R, 125E, 189G) in the NS1 of the 2009 pandemic H1N1 virus (H1N1pdm09), resulting in reduced IFN antagonism [254]. Interestingly, the NS1 of contemporary H1N1pdm09-descendants has gradually restored its ability to antagonize the IFN response by acquiring 6 specific aa residues, 55K, 90I, 123V, 125D, 131E, and 205S [255].

Beside the IFN antagonistic function of the NS1 protein, the PDZ-ligand binding motif (PBM) at the C-terminal end of NS1, commonly ESEV, KSEV, and RSEV, was shown to enhance the pathogenicity of 1918 H1N1 and HPAIV H5N1(KSEV) in mice [28,256]. Differently, the insertion of the PDZ-binding domain into the truncated NS1 protein of H1N1pdm09 did not show a significant impact on viral replication or virulence in mammals [257]. The PBM of avian IAV is directly implicated in tight-junction (TJ) disintegration. IAVs with particular PBM (ESEV) can directly disrupt TJ by mediating the NS1 binding to the host proteins Dgl1 and Scribble that are essential for the formation of TJ. However, as the ESEV motif is limited to a subset of avian IAV strains, direct targeting of TJ by NS1 might not occur in all IAV infections $[29,258]$.

In addition to gradual aa changes in the NS1 protein sequence, genetic shift or reassortment of the NS segment harbouring the NS1 gene extends the host range and tissue tropism, impairs the cellular immune response and alters the replication and pathogenicity of the reassortant virus in vitro and occasionally in vivo [27,244-246,259].

\section{Control and Prevention of IAV}

\subsection{Vaccination against IAV}

Vaccination is still the primary defence line and the most effective method to combat IAV infection [260] and would be needed to protect against spread of a zoonotic strain in the human population. Three types of influenza vaccines are currently licensed for human use: (1) inactivated whole- or split-virus; (2) live-attenuated virus; and (3) recombinant HA subunit vaccines. An influenza vaccine strain (IVS) is traditionally generated by co-inoculation of an IAV strain against which protective antibodies should be raised, together with the egg-adapted influenza virus A/Puerto Rico/8/1934 (H1N1, PR8) into embryonated eggs. The allantoic fluid is then harvested and highly replicating reassortant variants that provoke specific neutralizing and/or protective antibodies are identified by extensive genetic and antigenic screening [261,262]. To further improve the generation of IVS, reverse genetics (RG) systems have been employed to rescue recombinant IVS in a relatively short time overcoming the time consuming disadvantage of natural reassortment $[161,263,264]$. Using plasmid-based RG systems of IAV, the IVS possesses at least the immunogenic surface glycoproteins (HA and NA) of the circulating IAV in the genetic background of the PR8 strain [262,265].

Animal vaccination can reduce the chance of human infections with AIV with zoonotic potential. Nevertheless, AIV infections occur even in vaccinated birds and pigs and are frequently associated to 
vaccines, which demonstrated clear antigenic mismatches [266-268], or due to a novel introduction of an exotic strain or clade [110]. Consequently, the antigenic mismatch could result in an endemic situation due to delayed disease recognition and diagnosis, resulting in further spread of the infection among the sub-optimal vaccinated populations $[269,270]$. This is making it hard to select of a representative and genetically stable prepandemic candidate vaccine strain. Additionally, effective vaccination of animals against IAV can be influenced by several factors including, but not limited to, on-farm biosecurity measures [271,272], immune response of different bird species [272], immunosuppression, uncontrolled distribution and storage of the vaccines, and interference of maternal immunity with early vaccination of the offspring [273]. Rearing habits can also complicate the situation. For instance, mixing of various bird species, which is a common practice when raising backyard poultry in Egypt, can significantly hinder virus control. Kandeil and his colleagues indicated that vaccination is effective in backyard settings in Egypt. However, planning should consider the differential host responses and therefore vaccination effectiveness in the mixed species [272]. The low biosecurity conditions of backyard rearing and uncontrolled vaccination practices have probably fostered the generation of new antigenic variants of $\mathrm{H} 5 \mathrm{~N} 1$ in the Egyptian poultry sector over the last decade. Therefore, improving vaccination efficacy in domestic and backyard poultry must be considered as an important measure to prevent zoonotic transmission of AIV with pandemic risk potential.

Luckily, the human-to-human spread of H5N1 and H7N9 strains is yet not well established, which reduces the urgency to recommend a regular annual vaccination against both strains. Nevertheless, some countries maintain national stockpiles of pre-pandemic vaccines against AIVs (e.g., H5N1 and H7N9) to control infections if similar viruses should transmit from human-tohuman [274,275]. An inherent uncertainty inevitably associated is the fact that possible pandemic strains may be antigenically distinct from the stockpiled AI vaccines. To this point, these vaccines stockpiles should be regularly updated in response to new (relevant) knowledge that may become available.

\subsection{Antivirals against IAV}

Should a zoonotic AIV against which vaccines have not yet been generated infect and spread in the human population antivirals will be urgently needed. The momentarily available antiviral medications to control IAV infection are optimally prescribed within $48 \mathrm{~h}$ of symptom onset for patients admitted to the hospital with influenza-like illness and individuals at high risk of developing influenza-related complications. Several essential preventive and therapeutic strategies could help to combat epidemic and pandemic infection with zoonotic strains, including the stockpiling of anti-influenza drugs [276]. Currently, many different approaches are being pursued in experimental, pre-clinical work, or are at different stages in clinical trials. Here, we focused on four classes of antiviral drugs targeting different viral or cellular factors, which are either licenced in the European Union and the USA, or are available in specific countries, for the treatment and prophylaxis of influenza virus infections [277,278]. They include (I) adamantanes, (II) neuraminidase inhibitors, (III) membrane fusion inhibitors (Russia, China), and (IV) RNA-dependent RNA polymerase inhibitors (Japan). Furthermore, several anti-influenza drugs are in late-phase clinical trials (Figure 7) [277,279]. The members of the predefined classes are commonly used separately for anti-influenza treatment. However, preclinical studies have demonstrated that combinations of antiviral agents with different mode-of-action might be beneficial [277]. 


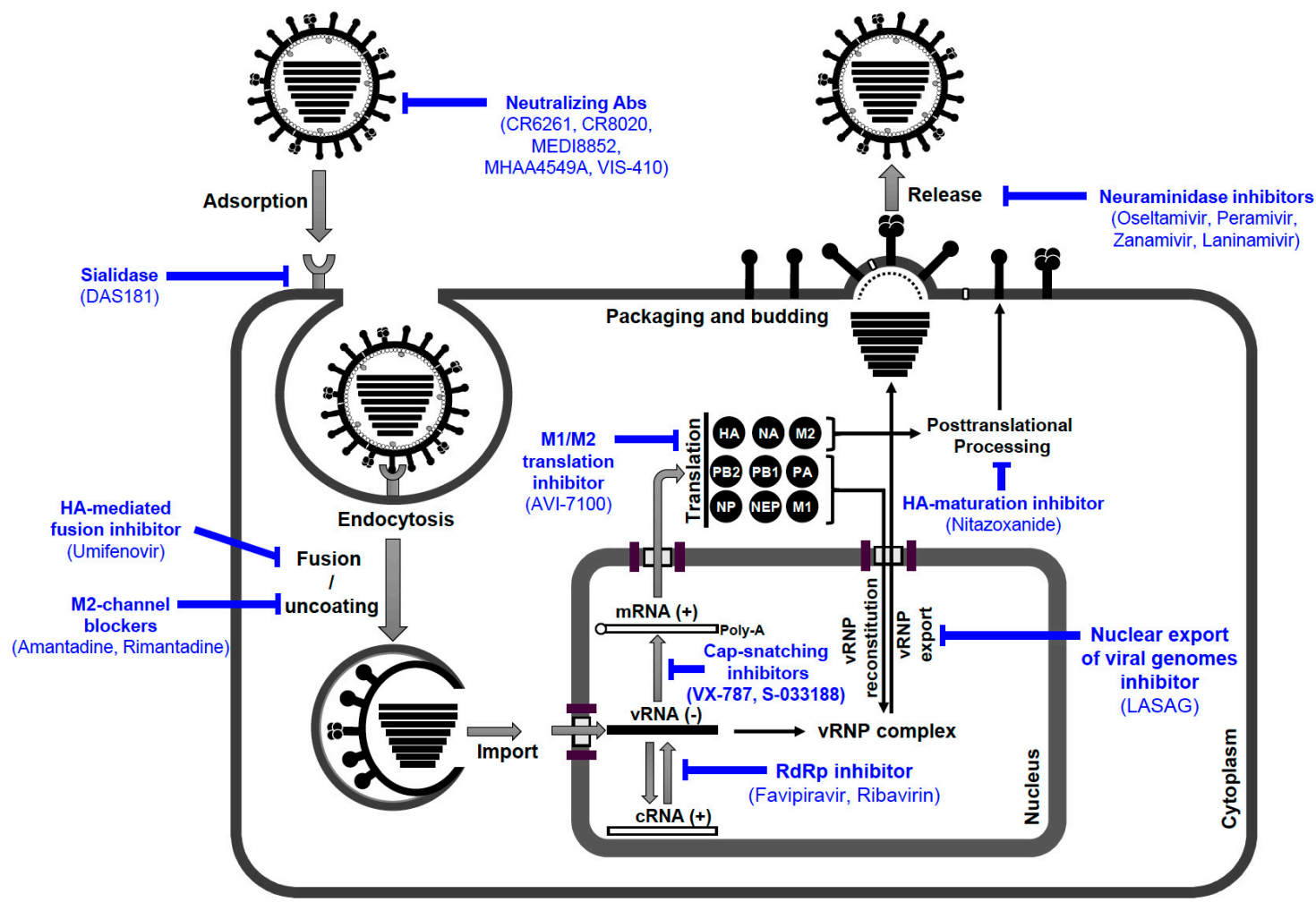

Figure 7. The targets of anti-influenza agents that are currently licensed or under clinically investigation. Before attachment of the influenza virus particle (IVP) to the host cell, specific neutralizing monoclonal antibodies (mAbs) against conserved domains in HA can prevent viral infection. Enzymatic destruction of the receptor determinant can further prevent IVP-binding to the target cells. After binding of the IVP to host cell sialic-acid receptors the viral life-cycle is continued by receptor-mediated endocytosis, HA-mediated fusion of the viral membrane with vesicular membrane, vRNP uncoating and release into the cytosol. The viral genome is then replicated/transcribed in the nucleus. After the viral mRNA has been translated into proteins some undergo post-translational processing in the cytosol or support genome replication in the nucleus. Newly formed vRNPs are exported from the nucleus and finally progeny virions are assembled and released by budding from the infected cell to infect new cells. These different processes are potential targets for the currently licensed antiviral drugs and others, which are in clinical trials including CR6261, CR8020, MEDI8852, MHAA4549A, VIS-410 (neutralizing Abs); DAS181 (sialidase); Umifenovir (fusion inhibitor); adamantanes (M2 channel blockers); Favipiravir and Ribavirin (RdRp inhibitors); VX-787 (PB2 cap-binding inhibitor); S-033188 (PA endonuclease inhibitor); AVI-7100 (inhibits M1/M2 mRNA-splicing); Nitazoxanide (HA maturation inhibitor); and Oseltamivir, Peramivir, Zanamivir, and Laninamivir (Neuraminidase inhibitors). In addition to its NF- $\kappa$ B inhibition effect, LASAG antagonizes the nuclear export of viral genomes and thereby blocks the assembly and release of mature influenza virus.

\subsubsection{Adamantanes}

The matrix protein 2 (M2) forms a homotetrameric integral membrane protein (97 aa). The M2 protein exerts an important proton channel activity that mediates the uncoating process through the acidification of the interior of the virion. This dissociates the M1 protein from the vRNPs mediating the release and the nuclear import of the vRNPs after HA-mediated fusion between viral and endosomal membrane [6]. Two orally active adamantane derivatives (amantadine, rimantadine) have been used for many years to control IAV infections by blocking the essential M2 channel function during the uncoating process of IAV, but they are not active against IBV [280,281]. However, resistance to both drugs has been vastly reported for the circulating seasonal IAVs and AIVs [281,282]. IAV resistance to adamantanes was associated with 6 aa mutations in the membrane-spanning region of the M2 
protein (L26F, V27A, A30T/V, S31N, G34E, and L38F) [280,282]. It is noteworthy that S31N is the most common adamantanes-resistance marker in human (98\%), avian (88\%), and swine (77\%) IAVs, followed by V27A [282-284]. Presently, the rapid emergence and the high resistance rates among seasonal and non-seasonal IAVs to adamantanes restricts their use for the treatment and prophylaxis of contemporary IAVs $[283,285,286]$.

\subsubsection{Neuraminidase Inhibitors}

The sialidase activity of NA is exerted by specific and highly conserved aa residues (active sites). These aa residues are differentiated into 8 catalytic- and 11 framework residues (Table 4) [287-289]. The catalytic residues interact directly with the substrate while the framework residues stabilize the catalytic residues. The catalytic site cleaves the $\alpha 2-3-S A$ and $\alpha 2-6-S A$ on the host cell membrane to release progeny virions from host cell. Therefore, inhibition of NA activity was thought to be an ideal strategy for antiviral drug development [288,290,291]. Neuraminidase inhibitors (NAIs), such as (1) orally administered oseltamivir (Tamiflu); (2) inhaled zanamivir (Relenza); and (3) intravenously applied peramivir (Rapivab), are FDA-approved anti-influenza drugs that act by inhibiting the sialidase activity of the IAV/IBV NA, thereby inhibiting the release of progeny virions from infected host cells [292]. Additionally, the inhaled Laninamivir (Inavir) is solely licensed in Japan for seasonal influenza viruses [293]. NAIs are currently the primary anti-influenza agents for the prevention and treatment of influenza virus infections, preferably within $48 \mathrm{~h}$ after onset of illness. [277,294]. Oseltamivir has been widely used because of its easy oral administration. However, zanamivir and peramivir are the drugs of choice when the effect of oseltamivir is limited due to oseltamivir-resistance. Due to differences in the chemical structures of the NAIs, resistance to oseltamivir may not necessarily confer resistance to the other two licensed NAIs, zanamivir and peramivir (Table 4) [295].

Regarding non-seasonal AIVs, the limited surveillance of the NAI sensitivity of circulating viruses, especially for the H5N1- and H7N9-strains, remains a problem. So far, only a few epidemiological/ antiviral studies have described H5N1 and H7N9 subtypes with reduced oseltamivir sensitivity, found with low prevalence in both poultry and humans in different geographical localities [296-300]. Nevertheless, being the only globally approved influenza-specific antiviral, different countries are maintaining licensed NAIs stockpiles as an approach for pandemic preparedness.

The effect of antiviral drug resistance relies primarily on the viral replication fitness of the drug-resistant variant versus the drug-sensitive strain. This was shown in studies that investigated the relevance of specific aa residues (known to confer NAI resistance) for neuraminidase activity, viral replication fitness, transmissibility and virulence in vitro and in vivo. However the results were not consistent and were dependent on the subtypes studied (e.g., H1N1, H3N2, H5N1, H7N9) and their particular genetic differences [291,301-304]. Generally, it seems that the effectiveness of NAIs is reduced when viral resistance does not, or only modestly, compromise viral fitness (unaltered virulence, transmission, and growth rate) [305]. Therefore, in addition to antiviral resistance a timely and accurate monitoring of strain fitness is of crucial importance to global public health [295,301,305].

Despite that NAIs are presently effective in controlling infections by seasonal and zoonotic IAV strains, the emergence and global spread of NAIs-resistant IAV variants is a concern, especially in areas of high level of NAI use like Japan [300]. Consequently, new antiviral agents targeting viral proteins / functions are needed (Figure 7). Furthermore, as the high genetic variability of IAV allows them to quickly adapt to selective pressures, new approaches must be considered. The fact that all viruses depend on specific cellular functions has led to a paradigm change in the antiviral strategy, aiming at certain cellular functions/mechanisms that could be inhibited to impair viral replication without severe effects on the host [306-308]. 
Table 4. Active site residues for all NA-subtypes and genetic resistance markers in viral NA proteins of highlighted non-seasonal human IAVs [288,290,291,296,300,304,308-312].

\begin{tabular}{|c|c|c|c|c|c|c|c|c|c|c|c|}
\hline \multicolumn{2}{|c|}{ NA Active Site (N2 Numbering) } & \multirow{3}{*}{$\begin{array}{l}\text { Influenza Virus } \\
\text { Type/Subtype }\end{array}$} & \multicolumn{9}{|c|}{ Resistance Marker (N2 Numbering)/Location within NA Active Site } \\
\hline \multirow{2}{*}{$\begin{array}{c}\text { Catalytic } \\
\text { Residues (CR) }\end{array}$} & \multirow{2}{*}{$\begin{array}{c}\text { Framework } \\
\text { Residues (FWR) }\end{array}$} & & \multicolumn{3}{|c|}{ Oseltamivir } & \multicolumn{2}{|l|}{ Zanamivir } & \multicolumn{2}{|l|}{ Peramivir } & \multicolumn{2}{|c|}{ Laninamivir } \\
\hline & & & & no Acid (aa) & Site & Amino Acid (aa) & Site & Amino Acid (aa) & Site & Amino Acid (aa) & Site \\
\hline \multirow{20}{*}{$\begin{array}{l}118 \mathrm{R} \\
151 \mathrm{D} \\
152 \mathrm{R} \\
224 \mathrm{R} \\
276 \mathrm{E} \\
292 \mathrm{R} \\
371 \mathrm{R} \\
406 \mathrm{Y}\end{array}$} & \multirow{20}{*}{$\begin{array}{c}119 \mathrm{E} \\
156 \mathrm{R} \\
178 \mathrm{~W} \\
179 \mathrm{~S} \\
198 \mathrm{D} \\
222 \mathrm{I} \\
227 \mathrm{E} \\
274 \mathrm{H} \\
277 \mathrm{E} \\
294 \mathrm{~N} \\
425 \mathrm{E}\end{array}$} & \multirow{20}{*}{$\begin{array}{c}\text { Non-seasonal } \\
\text { A/H5N1 }{ }^{+} \text {and } \\
\text { A/H7N9 }\end{array}$} & \multirow{12}{*}{$\mathrm{A} / \mathrm{H} 5 \mathrm{~N} 1$} & V116A & - & V116A & - & E119D/G & FWR & & \\
\hline & & & & E119A/D & FWR & E119A/D/G & FWR & H274Y & FWR & & \\
\hline & & & & Q136L & - & Q136L & - & N294S & FWR & & \\
\hline & & & & D198G & FWR & D198G & FWR & E119A/D/G + H274Y & FWR & & \\
\hline & & & & $\mathrm{I} 222 \mathrm{M}$ & FWR & $\mathrm{N} 294 \mathrm{~S}$ & FWR & $\mathrm{I} 222 \mathrm{M} / \mathrm{V}+\mathrm{H} 274 \mathrm{Y}$ & FWR & & \\
\hline & & & & $\mathrm{S} 246 \mathrm{~N}$ & - & $\mathrm{K} 432 \mathrm{~T}$ & - & & & & \\
\hline & & & & H274Y & FWR & E119A/D/G + H274Y & FWR & & & & \\
\hline & & & & N294S & FWR & & & & & & \\
\hline & & & & $\mathrm{I} 117 \mathrm{~V}+\mathrm{I} 314 \mathrm{~V}$ & - & & & & & & \\
\hline & & & & E119A/D/G + H274Y & FWR & & & & & & \\
\hline & & & & $\mathrm{I} 222 \mathrm{~L}+\mathrm{S} 246 \mathrm{~N}$ & FWR/- & & & & & & \\
\hline & & & & $\mathrm{I} 222 \mathrm{M} / \mathrm{V}+\mathrm{H} 274 \mathrm{Y}$ & FWR & & & & & & \\
\hline & & & \multirow{8}{*}{ A/H7N9 } & E119A/D & FWR & E119A/D/G & FWR & E119A/G & FWR & E119A & FWR \\
\hline & & & & $\mathrm{I} 222 \mathrm{~K} / \mathrm{R}$ & FWR & Q136K & - & E119D & FWR & E119D/G & FWR \\
\hline & & & & T247P & - & $\mathrm{I} 222 \mathrm{~K}$ & FWR & Q136K & - & Q136K & - \\
\hline & & & & $\mathrm{H} 274 \mathrm{Y}$ & FWR & T247P & - & $\mathrm{I} 222 \mathrm{~K}$ & FWR & R152K & $\mathrm{CR}$ \\
\hline & & & & E276D & $\mathrm{CR}$ & E276D & $\mathrm{CR}$ & E276D & $\mathrm{CR}$ & $\mathrm{I} 222 \mathrm{~K} / \mathrm{R}$ & FWR \\
\hline & & & & R292K & $\mathrm{CR}$ & R292K & $\mathrm{CR}$ & R292K & $\mathrm{CR}$ & E276D & $\mathrm{CR}$ \\
\hline & & & & R371K & $\mathrm{CR}$ & N294S & FWR & R371K & CR & R292K & $\mathrm{CR}$ \\
\hline & & & & $\mathrm{E} 119 \mathrm{~V}+\mathrm{E} 222 \mathrm{~V}$ & FWR & R371K & $\mathrm{CR}$ & & & R371K & $\mathrm{CR}$ \\
\hline
\end{tabular}

Bold refers to aa substitutions that confer high reduced inhibition (HRI) of NAI. Non-bold aa substitutions were shown to be associated with medium reduced inhibition. 


\subsubsection{Membrane Fusion Inhibitors}

As mentioned before, during the viral entry process, the $\mathrm{pH}$ decrease within the endosome leads to an irreversible conformational change in the HA2 subunit activating the fusion peptide, which interacts with the endosomal membrane to initiate the fusion process. Subsequently, the vRNPs are released into the cytoplasm and are then transported into the nucleus to initiate viral genome replication/transcription (Figure 7). Therefore, HA-mediated membrane fusion is targeted in antiinfluenza virus approaches $[277,278]$. Umifenovir (Arbidol) is a broad-spectrum antiviral drug licensed in Russia and China for prophylaxis and treatment of respiratory infections including seasonal influenza [277]. Umifenovir blocks the fusion process via targeting the conserved HA stem domain and prevents the low $\mathrm{pH}$-induced conformational rearrangements of the HA into its fusogenic state [277,313].

\subsubsection{RNA-Dependent RNA Polymerase (RdRp) Inhibitors}

The RdRp complex comprises conserved and independently folded subdomains with defined functionalities in viral transcription and replication. To date, T-705 (Favipiravir), a purine pseudobase inhibitor of RdRp, is licensed in Japan for the treatment and prophylaxis of pandemic influenza A/H1N1 [277]. Ribavirin is another purine pseudobase that interferes with viral replication of influenza viruses. However, different studies have shown that ribavirin is only efficient against IAVs when administered in synergistic combinations with oseltamivir and amantadine [314].

\subsection{Anti-Influenza Drugs in Late-Phase Clinical Trials}

Due to the expansion of drug-resistance to M2-blockers and NAIs, new therapeutic strategies have been developed targeting the cellular components such as sialic acid receptors, posttranslational processing of the viral proteins, or essential proviral intracellular signaling cascades. DAS181 (Fludase) is a recombinant sialidase, which is designed to be applied by inhalation to restrict the binding of influenza viruses to the host cell by removing sialic acid receptors from glycan structures on the human airway epithelia [278].

Nitazoxanide, an orally active anti-parasitic drug, controls IAV infection by impairing the trafficking of the HA from the endoplasmic reticulum (ER) to the Golgi and inhibiting HA maturation by blocking HA terminal glycosylation. It also stimulates antiviral cellular innate immunity via interferon induction $[277,278]$.

Currently, further inhibitors are under investigation in late-phase clinical trials: (i) VX-787, an orally active inhibitor of PB2; (ii) S-033188, an orally active PA inhibitor; and (iii) AVI-7100, intravenously active, small interfering antisense RNA constructs, targeting influenza M1/M2 translation [277,278,287]. More recently, Scheuch et al. showed that intranasally administered D,L-lysine-acetylsalicylate-glycine (LASAG), an anti-inflammatory derivative of Aspirin, resulted in a significantly faster alleviation of influenza symptoms, more rapid decline in viral shedding, and decreased risk of viral spread [306]. LASAG acts by inhibiting IKK-mediated NF-kB activity and blocking nuclear export of viral genomes [306]. The in vitro treatment with LASAG was not associated with the emergence of viral resistance [306,315].

Furthermore, five monoclonal antibodies that efficiently neutralize invading IAV are under evaluation in clinical trials. These mAbs target either the globular head or the highly conserved stem region of the viral HA, or the conserved ectodomain of the M2 (M2e); namely CR6261, CR8020, MEDI8852, MHAA4549A, and VIS-410 [277,278].

\section{Conclusions}

More than $50 \%$ of all human viral infections can be transmitted from animals. The One Health approach is based on the fact that animal, human and environmental healths are interrelated. A hundred years ago in 1918-1919, mankind was confronted with the first documented influenza pandemic of the 20th century, representing a devastating global occasion of influenza virus infections. 
Since then, influenza viruses showed a high genetic and antigenic diversity either by gradual acquisition of particular changes (antigenic drift) important for the adaptation to a new host or by monogenic/polygenic reassortment events (antigenic shift). This wide diversity of IAVs permitted them to adapt to different avian and mammalian host species including humans. In recent years, new AIVs emerged that have evolved independently to cross animal/human interface and have caused mild to fatal complications in human. Despite the massive screening for new antiviral drugs against influenza viruses, limited numbers of FDA-licensed or conditionally/regionally licensed anti-influenza drugs are available as a preventive strategy. Therefore, a better understanding of the genesis of newly emerging IAVs, improved surveillance efforts and intensified research to monitor and understand these foes are mandatory. Virtually, the One Health concept, a collaborative effort of different specialized experts across animal, human and environmental health to ameliorate animal and human health, must be implemented to fight against the high-consequence zoonotic AIVs.

Author Contributions: All authors analyzed the literature and wrote the manuscript.

Funding: This research was funded in part by the German Research Foundation (DFG) (AB567/1-2 und VE780/1-1 to E.M.A.), the EU Horizon 2020 (DELTA-FLU to E.M.A.), and by the DFG-funded SFB/TR 84 (Innate Immunity of the Lu ng: Mechanisms of Pathogen Attack and Host Defense in Pneumonia, TP B2 to S.P.) and SFB 1021 (RNA viruses: RNA metabolism, host response and pathogenesis, TP C1 to S.P.) and a postdoctoral fellowship (Just'us to A.M.) of the Justus Liebig University, Giessen, Germany. S.P. is a member of the German FluResearchNet, a nationwide research network on zoonotic influenza. The APC was funded by the Justus Liebig University, Giessen, Germany.

Conflicts of Interest: The authors declare no conflict of interest.

\section{References}

1. Hause, B.M.; Collin, E.A.; Liu, R.; Huang, B.; Sheng, Z.; Lu, W.; Wang, D.; Nelson, E.A.; Li, F. Characterization of a novel influenza virus in cattle and Swine: Proposal for a new genus in the orthomyxoviridae family. mBio 2014, 5, e00031-14. [CrossRef] [PubMed]

2. Chiapponi, C.; Faccini, S.; De Mattia, A.; Baioni, L.; Barbieri, I.; Rosignoli, C.; Nigrelli, A.; Foni, E. Detection of influenza d virus among swine and cattle, Italy. Emerg. Infect. Dis. 2016, 22, 352-354. [CrossRef] [PubMed]

3. Shaw, M.L.; Palese, P. Orthomyxoviridae, 6th ed.; Lippincott Williams \& Wilkins: Philadelphia, PA, USA, 2013; Volume 1, pp. 1151-1185.

4. Skehel, J.J.; Wiley, D.C. Receptor binding and membrane fusion in virus entry: The influenza hemagglutinin. Annu. Rev. Biochem. 2000, 69, 531-569. [CrossRef] [PubMed]

5. Wilson, I.A.; Skehel, J.J.; Wiley, D.C. Structure of the haemagglutinin membrane glycoprotein of influenza virus at 3 A resolution. Nature 1981, 289, 366-373. [CrossRef] [PubMed]

6. Pinto, L.H.; Holsinger, L.J.; Lamb, R.A. Influenza virus M2 protein has ion channel activity. Cell 1992, 69, 517-528. [CrossRef]

7. Hutchinson, E.C.; Charles, P.D.; Hester, S.S.; Thomas, B.; Trudgian, D.; Martinez-Alonso, M.; Fodor, E. Conserved and host-specific features of influenza virion architecture. Nat. Commun. 2014, 5, 4816. [CrossRef] [PubMed]

8. Pleschka, S. Overview of influenza viruses. Curr. Top. Microbiol. Immunol. 2013, 370, 1-20. [PubMed]

9. Iwai, A.; Shiozaki, T.; Kawai, T.; Akira, S.; Kawaoka, Y.; Takada, A.; Kida, H.; Miyazaki, T. Influenza a virus polymerase inhibits type I interferon induction by binding to interferon beta promoter stimulator 1. J. Biol. Chem. 2010, 285, 32064-32074. [CrossRef] [PubMed]

10. Yamayoshi, S.; Watanabe, M.; Goto, H.; Kawaoka, Y. Identification of a novel viral protein expressed from the pb2 segment of influenza a virus. J. Virol. 2016, 90, 444-456. [CrossRef] [PubMed]

11. Schmolke, M.; Manicassamy, B.; Pena, L.; Sutton, T.; Hai, R.; Varga, Z.T.; Hale, B.G.; Steel, J.; Perez, D.R.; Garcia-Sastre, A. Differential contribution of pb1-f2 to the virulence of highly pathogenic h5n1 influenza a virus in mammalian and avian species. PLoS Pathog. 2011, 7, e1002186. [CrossRef] [PubMed]

12. Varga, Z.T.; Ramos, I.; Hai, R.; Schmolke, M.; Garcia-Sastre, A.; Fernandez-Sesma, A.; Palese, P. The influenza virus protein pb1-f2 inhibits the induction of type I interferon at the level of the MAVS adaptor protein. PLoS Pathog. 2011, 7, e1002067. [CrossRef] [PubMed] 
13. Krumbholz, A.; Philipps, A.; Oehring, H.; Schwarzer, K.; Eitner, A.; Wutzler, P.; Zell, R. Current knowledge on pb1-f2 of influenza A viruses. Med. Microbiol. Immunol. 2011, 200, 69-75. [CrossRef] [PubMed]

14. McAuley, J.L.; Hornung, F.; Boyd, K.L.; Smith, A.M.; McKeon, R.; Bennink, J.; Yewdell, J.W.; McCullers, J.A. Expression of the 1918 influenza a virus pb1-f2 enhances the pathogenesis of viral and secondary bacterial pneumonia. Cell Host Microbe 2007, 2, 240-249. [CrossRef] [PubMed]

15. Zamarin, D.; Ortigoza, M.B.; Palese, P. Influenza A virus pb1-f2 protein contributes to viral pathogenesis in mice. J. Virol. 2006, 80, 7976-7983. [CrossRef] [PubMed]

16. Chakrabarti, A.K.; Pasricha, G. An insight into the pb1f2 protein and its multifunctional role in enhancing the pathogenicity of the influenza A viruses. Virology 2013, 440, 97-104. [CrossRef] [PubMed]

17. Tauber, S.; Ligertwood, Y.; Quigg-Nicol, M.; Dutia, B.M.; Elliott, R.M. Behaviour of influenza A viruses differentially expressing segment 2 gene products in vitro and in vivo. J. Gen. Virol. 2012, 93, 840-849. [CrossRef] [PubMed]

18. Wise, H.M.; Foeglein, A.; Sun, J.; Dalton, R.M.; Patel, S.; Howard, W.; Anderson, E.C.; Barclay, W.S.; Digard, P. A complicated message: Identification of a novel PB1-related protein translated from influenza a virus segment 2 mRNA. J. Virol. 2009, 83, 8021-8031. [CrossRef] [PubMed]

19. Gao, H.; Sun, Y.; Hu, J.; Qi, L.; Wang, J.; Xiong, X.; Wang, Y.; He, Q.; Lin, Y.; Kong, W.; et al. The contribution of pa-x to the virulence of pandemic 2009 h1n1 and highly pathogenic h5n1 avian influenza viruses. Sci. Rep. 2015, 5, 8262. [CrossRef] [PubMed]

20. Hu, J.; Mo, Y.; Wang, X.; Gu, M.; Hu, Z.; Zhong, L.; Wu, Q.; Hao, X.; Hu, S.; Liu, W.; et al. Pa-x decreases the pathogenicity of highly pathogenic $\mathrm{h} 5 \mathrm{n} 1$ influenza a virus in avian species by inhibiting virus replication and host response. J. Virol. 2015. [CrossRef] [PubMed]

21. Shi, M.; Jagger, B.W.; Wise, H.M.; Digard, P.; Holmes, E.C.; Taubenberger, J.K. Evolutionary conservation of the pa-x open reading frame in segment 3 of influenza a virus. J. Virol. 2012, 86, 12411-12413. [CrossRef] [PubMed]

22. Muramoto, Y.; Noda, T.; Kawakami, E.; Akkina, R.; Kawaoka, Y. Identification of novel influenza a virus proteins translated from pa mRNA. J. Virol. 2013, 87, 2455-2462. [CrossRef] [PubMed]

23. Wang, Q.; Li, Q.; Liu, T.; Chang, G.; Sun, Z.; Gao, Z.; Wang, F.; Zhou, H.; Liu, R.; Zheng, M.; et al. Host interaction analysis of pa-n155 and pa-n182 in chicken cells reveals an essential role of uba52 for replication of h5n1 avian influenza virus. Front. Microbiol. 2018, 9, 936. [CrossRef] [PubMed]

24. Bui, M.; Wills, E.G.; Helenius, A.; Whittaker, G.R. Role of the influenza virus $\mathrm{m} 1$ protein in nuclear export of viral ribonucleoproteins. J. Virol. 2000, 74, 1781-1786. [CrossRef] [PubMed]

25. Wise, H.M.; Hutchinson, E.C.; Jagger, B.W.; Stuart, A.D.; Kang, Z.H.; Robb, N.; Schwartzman, L.M.; Kash, J.C.; Fodor, E.; Firth, A.E.; et al. Identification of a novel splice variant form of the influenza a virus $\mathrm{m} 2$ ion channel with an antigenically distinct ectodomain. PLoS Pathog. 2012, 8, e1002998. [CrossRef] [PubMed]

26. Pereira, C.F.; Read, E.K.C.; Wise, H.M.; Amorim, M.J.; Digard, P. Influenza a virus ns1 protein promotes efficient nuclear export of unspliced viral M1 mRNA. J. Virol. 2017, 91. [CrossRef] [PubMed]

27. Ayllon, J.; Garcia-Sastre, A. The NS1 protein: A multitasking virulence factor. Curr. Top. Microbiol. Immunol. 2015, 386, 73-107. [PubMed]

28. Fan, S.; Macken, C.A.; Li, C.; Ozawa, M.; Goto, H.; Iswahyudi, N.F.; Nidom, C.A.; Chen, H.; Neumann, G.; Kawaoka, Y. Synergistic effect of the pdz and p85beta-binding domains of the ns1 protein on virulence of an avian H5N1 influenza A virus. J. Virol. 2013, 87, 4861-4871. [CrossRef] [PubMed]

29. Golebiewski, L.; Liu, H.; Javier, R.T.; Rice, A.P. The avian influenza virus NS1 ESEV PDZ binding motif associates with dlg1 and scribble to disrupt cellular tight junctions. J. Virol. 2011, 85, 10639-10648. [CrossRef] [PubMed]

30. Hale, B.G.; Randall, R.E.; Ortin, J.; Jackson, D. The multifunctional ns1 protein of influenza A viruses. J. Gen. Virol. 2008, 89, 2359-2376. [CrossRef] [PubMed]

31. Robb, N.C.; Smith, M.; Vreede, F.T.; Fodor, E. Ns2/nep protein regulates transcription and replication of the influenza virus RNA genome. J. Gen. Virol. 2009, 90, 1398-1407. [CrossRef] [PubMed]

32. Neumann, G.; Hughes, M.T.; Kawaoka, Y. Influenza a virus ns2 protein mediates vrnp nuclear export through nes-independent interaction with hcrm1. EMBO J. 2000, 19, 6751-6758. [CrossRef] [PubMed]

33. O'Neill, R.E.; Talon, J.; Palese, P. The influenza virus nep (ns2 protein) mediates the nuclear export of viral ribonucleoproteins. EMBO J. 1998, 17, 288-296. [CrossRef] [PubMed] 
34. Yasuda, J.; Nakada, S.; Kato, A.; Toyoda, T.; Ishihama, A. Molecular assembly of influenza virus: Association of the ns2 protein with virion matrix. Virology 1993, 196, 249-255. [CrossRef] [PubMed]

35. Selman, M.; Dankar, S.K.; Forbes, N.E.; Jia, J.-J.; Brown, E.G. Adaptive mutation in influenza a virus non-structural gene is linked to host switching and induces a novel protein by alternative splicing. Emerg. Microbes Infect. 2012, 1, e42. [CrossRef] [PubMed]

36. Pleschka, S.; Jaskunas, R.; Engelhardt, O.G.; Zurcher, T.; Palese, P.; Garcia-Sastre, A. A plasmid-based reverse genetics system for influenza a virus. J. Virol. 1996, 70, 4188-4192. [PubMed]

37. Neumann, G.; Watanabe, T.; Ito, H.; Watanabe, S.; Goto, H.; Gao, P.; Hughes, M.; Perez, D.R.; Donis, R.; Hoffmann, E.; et al. Generation of influenza A viruses entirely from cloned cDNAs. Proc. Natl. Acad. Sci. USA 1999, 96, 9345-9350. [CrossRef] [PubMed]

38. Fodor, E.; Devenish, L.; Engelhardt, O.G.; Palese, P.; Brownlee, G.G.; Garcia-Sastre, A. Rescue of influenza A virus from recombinant DNA. J. Virol. 1999, 73, 9679-9682. [PubMed]

39. Tong, S.; Li, Y.; Rivailler, P.; Conrardy, C.; Castillo, D.A.; Chen, L.M.; Recuenco, S.; Ellison, J.A.; Davis, C.T.; York, I.A.; et al. A distinct lineage of influenza A virus from bats. Proc. Natl. Acad. Sci. USA 2012, 109, 4269-4274. [CrossRef] [PubMed]

40. Tong, S.; Zhu, X.; Li, Y.; Shi, M.; Zhang, J.; Bourgeois, M.; Yang, H.; Chen, X.; Recuenco, S.; Gomez, J.; et al. New world bats harbor diverse influenza A viruses. PLoS Pathog. 2013, 9, e1003657. [CrossRef] [PubMed]

41. Wu, Y.; Tefsen, B.; Shi, Y.; Gao, G.F. Bat-derived influenza-like viruses h17n10 and h18n11. Trends Microbiol. 2014, 22, 183-191. [CrossRef] [PubMed]

42. Wright, P.F.; Neumann, G.; Kawaoka, Y. Orthomyxoviruses; Lippincott Williams \& Wilkins: Philadelphia, PA, USA, 2013; Volume 1, pp. 1186-1241.

43. Webster, R.G.; Bean, W.J.; Gorman, O.T.; Chambers, T.M.; Kawaoka, Y. Evolution and ecology of Influenza A viruses. Microbiol. Rev. 1992, 56, 152-179. [PubMed]

44. Short, K.R.; Richard, M.; Verhagen, J.H.; van Riel, D.; Schrauwen, E.J.A.; van den Brand, J.M.A.; Mänz, B.; Bodewes, R.; Herfst, S. One health, multiple challenges: The inter-species transmission of Influenza A virus. One Health 2015, 1, 1-13. [CrossRef] [PubMed]

45. Gatherer, D. The 2009 h1n1 influenza outbreak in its historical context. J. Clin. Virol. 2009, 45, 174-178. [CrossRef] [PubMed]

46. Hay, A.J.; Gregory, V.; Douglas, A.R.; Lin, Y.P. The evolution of human influenza viruses. Philos. Trans. R. Soc. Lond. Ser. B Biol. Sci. 2001, 356, 1861-1870.

47. Lessler, J.; Reich, N.G.; Cummings, D.A.; Nair, H.P.; Jordan, H.T.; Thompson, N. Outbreak of 2009 pandemic influenza A (h1n1) at a New York City school. N. Engl. J. Med. 2009, 361, 2628-2636. [CrossRef] [PubMed]

48. Reid, A.H.; Fanning, T.G.; Hultin, J.V.; Taubenberger, J.K. Origin and evolution of the 1918 "Spanish" influenza virus hemagglutinin gene. Proc. Natl. Acad. Sci. USA 1999, 96, 1651-1656. [CrossRef] [PubMed]

49. Parry, J. H7N9 avian flu infects humans for the first time. BMJ 2013, 346, f2151. [CrossRef] [PubMed]

50. To, K.K.; Tsang, A.K.; Chan, J.F.; Cheng, V.C.; Chen, H.; Yuen, K.Y. Emergence in China of human disease due to avian influenza a(h10n8)—Cause for concern? J. Infect. 2014, 68, 205-215. [CrossRef] [PubMed]

51. Yuen, K.Y.; Chan, P.K.; Peiris, M.; Tsang, D.N.; Que, T.L.; Shortridge, K.F.; Cheung, P.T.; To, W.K.; Ho, E.T.; Sung, R.; et al. Clinical features and rapid viral diagnosis of human disease associated with avian influenza a h5n1 virus. Lancet 1998, 351, 467-471. [CrossRef]

52. Shi, W.; Shi, Y.; Wu, Y.; Liu, D.; Gao, G.F. Origin and molecular characterization of the human-infecting h6n1 influenza virus in Taiwan. Protein Cell 2013, 4, 846-853. [CrossRef] [PubMed]

53. Wong, S.S.; Yuen, K.Y. Avian influenza virus infections in humans. Chest 2006, 129, 156-168. [CrossRef] [PubMed]

54. WHO. Human Infection with Avian Influenza A(H7n4) Virus-China. Available online: http://www.Who. Int/csr/don/22-february-2018-ah7n4-china/en/ (accessed on 24 February 2018).

55. Chen, H.; Yuan, H.; Gao, R.; Zhang, J.; Wang, D.; Xiong, Y.; Fan, G.; Yang, F.; Li, X.; Zhou, J.; et al. Clinical and epidemiological characteristics of a fatal case of avian influenza A H10N8 virus infection: A descriptive study. Lancet 2014, 383, 714-721. [CrossRef]

56. Daszak, P.; Cunningham, A.A.; Hyatt, A.D. Emerging infectious diseases of wildlife-Threats to biodiversity and human health. Science 2000, 287, 443-449. [CrossRef] [PubMed]

57. Swayne, D.E.; Suarez, D.L. Highly pathogenic avian influenza. Rev. Sci. Tech. 2000, 19, 463-482. [CrossRef] [PubMed] 
58. Steinhauer, D.A. Role of hemagglutinin cleavage for the pathogenicity of influenza virus. Virology 1999, 258, 1-20. [CrossRef] [PubMed]

59. OIE. Highly Pathogenic Avian Influenza, Ghana. Available online: http://www.oie.int/wahis_2/pu blic/wahid.php/Reviewreport/Review?page_refer=MapFullEventReport\&reportid=25915 (accessed on 24 February 2018).

60. Alexander, D.J. A review of avian influenza in different bird species. Vet. Microbiol. 2000, 74, 3-13. [CrossRef]

61. Chen, J.; Lee, K.H.; Steinhauer, D.A.; Stevens, D.J.; Skehel, J.J.; Wiley, D.C. Structure of the hemagglutinin precursor cleavage site, a determinant of influenza pathogenicity and the origin of the labile conformation. Cell 1998, 95, 409-417. [CrossRef]

62. Pereira, H.G.; Tumova, B.; Law, V.G. Avian influenza A viruses. Bull. World Health Organ. 1965, 32, 855-860. [PubMed]

63. Becker, W.B. The isolation and classification of tern virus: Influenza a-tern South Africa-1961. J. Hyg. 1966, 64, 309-320. [CrossRef] [PubMed]

64. Chen, H.; Smith, G.J.; Zhang, S.Y.; Qin, K.; Wang, J.; Li, K.S.; Webster, R.G.; Peiris, J.S.; Guan, Y. Avian flu: H5n1 virus outbreak in migratory waterfowl. Nature 2005, 436, 191-192. [CrossRef] [PubMed]

65. Bi, Y.; Zhang, Z.; Liu, W.; Yin, Y.; Hong, J.; Li, X.; Wang, H.; Wong, G.; Chen, J.; Li, Y.; et al. Highly pathogenic avian influenza a(h5n1) virus struck migratory birds in China in 2015. Sci. Rep. 2015, 5, 12986. [CrossRef] [PubMed]

66. Selim, A.A.; Erfan, A.M.; Hagag, N.; Zanaty, A.; Samir, A.H.; Samy, M.; Abdelhalim, A.; Arafa, A.A.; Soliman, M.A.; Shaheen, M.; et al. Highly pathogenic avian influenza virus (h5n8) clade 2.3.4.4 infection in migratory birds, Egypt. Emerg. Infect. Dis. 2017, 23, 1048-1051. [CrossRef] [PubMed]

67. Li, M.; Liu, H.; Bi, Y.; Sun, J.; Wong, G.; Liu, D.; Li, L.; Liu, J.; Chen, Q.; Wang, H.; et al. Highly Pathogenic avian influenza a(h5n8) virus in wild migratory birds, Qinghai Lake, China. Emerg. Infect. Dis. 2017, 23, 637-641. [CrossRef] [PubMed]

68. Capua, I.; Alexander, D.J. Human health implications of avian influenza viruses and paramyxoviruses. Eur. J. Clin. Microbiol. Infect. Dis. 2004, 23, 1-6. [CrossRef] [PubMed]

69. Luo, S.; Xie, Z.; Xie, Z.; Xie, L.; Huang, L.; Huang, J.; Deng, X.; Zeng, T.; Wang, S.; Zhang, Y.; et al. Surveillance of live poultry markets for low pathogenic avian influenza viruses in Guangxi Province, Southern China, from 2012-2015. Sci. Rep. 2017, 7, 17577. [CrossRef] [PubMed]

70. Zhang, G.; Kong, W.; Qi, W.; Long, L.-P.; Cao, Z.; Huang, L.; Qi, H.; Cao, N.; Wang, W.; Zhao, F.; et al. Identification of an H6N6 swine influenza virus in southern China. Infect. Genet. Evol. J. Mol. Epidemiol. Evol. Genet. Infect. Dis. 2011, 11, 1174-1177. [CrossRef] [PubMed]

71. Nelson, M.I.; Holmes, E.C. The evolution of epidemic influenza. Nat. Rev. Genet. 2007, 8, 196-205. [CrossRef] [PubMed]

72. Fourment, M.; Holmes, E.C. Avian influenza virus exhibits distinct evolutionary dynamics in wild birds and poultry. BMC Evol. Biol. 2015, 15, 120. [CrossRef] [PubMed]

73. Conenello, G.M.; Tisoncik, J.R.; Rosenzweig, E.; Varga, Z.T.; Palese, P.; Katze, M.G. A single N66S mutation in the PB1-F2 protein of influenza A virus increases virulence by inhibiting the early interferon response in vivo. J. Virol. 2011, 85, 652-662. [CrossRef] [PubMed]

74. Urbaniak, K.; Markowska-Daniel, I. In vivo reassortment of influenza viruses. Acta Biochim. Pol. 2014, 61, 427-431. [PubMed]

75. Ozawa, M.; Kawaoka, Y. Crosstalk between animal and human influenza viruses. Annu. Rev. Anim. Biosci. 2013, 1, 21-42. [CrossRef] [PubMed]

76. Medina, R.A.; Garcia-Sastre, A. Influenza A viruses: New research developments. Nat. Rev. Microbiol. 2011, 9, 590-603. [CrossRef] [PubMed]

77. Garten, R.J.; Davis, C.T.; Russell, C.A.; Shu, B.; Lindstrom, S.; Balish, A.; Sessions, W.M.; Xu, X.; Skepner, E.; Deyde, V.; et al. Antigenic and genetic characteristics of swine-origin 2009 a(h1n1) influenza viruses circulating in humans. Science 2009, 325, 197-201. [CrossRef] [PubMed]

78. Broberg, E.; Snacken, R.; Adlhoch, C.; Beaute, J.; Galinska, M.; Pereyaslov, D.; Brown, C.; Penttinen, P.; Collective on behalf of the WHO European Region; The European Influenza Surveillance Network. Start of the 2014/15 influenza season in Europe: Drifted influenza a(h3n2) viruses circulate as dominant subtype. Eur. Commun. Dis. Bull. 2015, 20. [CrossRef] 
79. Meijer, A.; Swaan, C.M.; Voerknecht, M.; Jusic, E.; van den Brink, S.; Wijsman, L.A.; Voordouw, B.C.; Donker, G.A.; Sleven, J.; Dorigo-Zetsma, W.W.; et al. Case of seasonal reassortant a(h1n2) influenza virus infection, the Netherlands, March 2018. Eurosurveillance 2018, 23. [CrossRef] [PubMed]

80. Claas, E.C.; Osterhaus, A.D.; van Beek, R.; De Jong, J.C.; Rimmelzwaan, G.F.; Senne, D.A.; Krauss, S.; Shortridge, K.F.; Webster, R.G. Human influenza a h5n1 virus related to a highly pathogenic avian influenza virus. Lancet 1998, 351, 472-477. [CrossRef]

81. Subbarao, K.; Klimov, A.; Katz, J.; Regnery, H.; Lim, W.; Hall, H.; Perdue, M.; Swayne, D.; Bender, C.; Huang, J.; et al. Characterization of an avian influenza a (h5n1) virus isolated from a child with a fatal respiratory illness. Science 1998, 279, 393-396. [CrossRef] [PubMed]

82. Bahgat, M.M.; Kutkat, M.A.; Nasraa, M.H.; Mostafa, A.; Webby, R.; Bahgat, I.M.; Ali, M.A. Characterization of an avian influenza virus h5n1 Egyptian isolate. J. Virol. Methods 2009, 159, 244-250. [CrossRef] [PubMed]

83. Abdelwhab, E.M.; Hassan, M.K.; Abdel-Moneim, A.S.; Naguib, M.M.; Mostafa, A.; Hussein, I.T.; Arafa, A.; Erfan, A.M.; Kilany, W.H.; Agour, M.G.; et al. Introduction and enzootic of a/h5n1 in Egypt: Virus evolution, pathogenicity and vaccine efficacy ten years on. Infect. Genet. Evol. 2016, 40, 80-90. [CrossRef] [PubMed]

84. Alexander, D.J. Avian influenza viruses and human health. Dev. Biol. 2006, 124, 77-84.

85. Tweed, S.A.; Skowronski, D.M.; David, S.T.; Larder, A.; Petric, M.; Lees, W.; Li, Y.; Katz, J.; Krajden, M.; Tellier, R.; et al. Human illness from avian influenza h7n3, British Columbia. Emerg. Infect. Dis. 2004, 10, 2196-2199. [CrossRef] [PubMed]

86. Koopmans, M.; Wilbrink, B.; Conyn, M.; Natrop, G.; van der Nat, H.; Vennema, H.; Meijer, A.; van Steenbergen, J.; Fouchier, R.; Osterhaus, A.; et al. Transmission of h7n7 avian influenza A virus to human beings during a large outbreak in commercial poultry farms in the Netherlands. Lancet 2004, 363, 587-593. [CrossRef]

87. Abdelwhab, E.M.; Abdel-Moneim, A.S. Epidemiology, ecology and gene pool of influenza A virus in Egypt: Will Egypt be the epicentre of the next influenza pandemic? Virulence 2015, 6, 6-18. [CrossRef] [PubMed]

88. Wu, A.; Su, C.; Wang, D.; Peng, Y.; Liu, M.; Hua, S.; Li, T.; Gao, G.F.; Tang, H.; Chen, J.; et al. Sequential reassortments underlie diverse influenza h7n9 genotypes in China. Cell Host Microbe 2013, 14, 446-452. [CrossRef] [PubMed]

89. Qi, W.; Zhou, X.; Shi, W.; Huang, L.; Xia, W.; Liu, D.; Li, H.; Chen, S.; Lei, F.; Cao, L.; et al. Genesis of the novel human-infecting influenza a(h10n8) virus and potential genetic diversity of the virus in poultry, China. Eur Surveill. 2014, 19, 20841. [CrossRef]

90. Lam, T.T.; Wang, J.; Shen, Y.; Zhou, B.; Duan, L.; Cheung, C.L.; Ma, C.; Lycett, S.J.; Leung, C.Y.; Chen, X.; et al. The genesis and source of the h7n9 influenza viruses causing human infections in China. Nature 2013, 502, 241-244. [CrossRef] [PubMed]

91. WHO. Cumulative Number of Confirmed Human Cases of Avian Influenza A(H5n1) Reported to WHO. Available online: http:/ / www.who.int/influenza/human_animal_interface/H5N1_cumulative_table_ar chives/en/ (accessed on 19 July 2018).

92. EMPRES. Disease Events. Available online: http:/ / empres-i.fao.org/eipws3g/ (accessed on 19 July 2018).

93. FAO. H7N9 Situation Update. Available online: http://www.fao.org/ag/againfo/programmes/en/empre s/h7n9/situation_update.html (accessed on 19 July 2018).

94. Lin, Y.P.; Shaw, M.; Gregory, V.; Cameron, K.; Lim, W.; Klimov, A.; Subbarao, K.; Guan, Y.; Krauss, S.; Shortridge, K.; et al. Avian-to-human transmission of h9n2 subtype influenza A viruses: Relationship between h9n2 and H5N1 human isolates. Proc. Natl. Acad. Sci. USA 2000, 97, 9654-9658. [CrossRef] [PubMed]

95. Guan, Y.; Shortridge, K.F.; Krauss, S.; Webster, R.G. Molecular characterization of h9n2 influenza viruses: Were they the donors of the "internal" genes of h5n1 viruses in Hong Kong? Proc. Natl. Acad. Sci. USA 1999, 96, 9363-9367. [CrossRef] [PubMed]

96. Monne, I.; Yamage, M.; Dauphin, G.; Claes, F.; Ahmed, G.; Giasuddin, M.; Salviato, A.; Ormelli, S.; Bonfante, F.; Schivo, A.; et al. Reassortant avian influenza a(h5n1) viruses with h9n2-pb1 gene in poultry, Bangladesh. Emerg. Infect. Dis. 2013, 19, 1630-1634. [CrossRef] [PubMed]

97. Lei, F.; Shi, W. Prospective of genomics in revealing transmission, reassortment and evolution of wildlifeborne avian influenza a (h5n1) Viruses. Curr. Genomics 2011, 12, 466-474. [CrossRef] [PubMed]

98. Gerloff, N.A.; Khan, S.U.; Balish, A.; Shanta, I.S.; Simpson, N.; Berman, L.; Haider, N.; Poh, M.K.; Islam, A.; Gurley, E.; et al. Multiple reassortment events among highly pathogenic avian influenza a(h5n1) viruses detected in Bangladesh. Virology 2014, 450-451, 297-307. [CrossRef] [PubMed] 
99. WHO. Continued evolution of highly pathogenic avian influenza A (h5n1): Updated nomenclature. Influenza Other Respir. Viruses 2012, 6, 1-5. [CrossRef] [PubMed]

100. World Health Organization/World Organisation for Animal Health/Food; Agriculture Organization (WHO/OIE/FAO) H5N1 Evolution Working Group. Revised and updated nomenclature for highly pathogenic avian influenza A (H5N1) viruses. Influenza Other Respir. Viruses 2014, 8, 384-388. [CrossRef] [PubMed]

101. Lee, D.H.; Bertran, K.; Kwon, J.H.; Swayne, D.E. Evolution, global spread, and pathogenicity of highly pathogenic avian influenza H5Nx clade 2.3.4.4. J. Vet. Sci. 2017, 18, 269-280. [CrossRef] [PubMed]

102. Vijaykrishna, D.; Bahl, J.; Riley, S.; Duan, L.; Zhang, J.X.; Chen, H.; Peiris, J.S.M.; Smith, G.J.D.; Guan, Y. Evolutionary Dynamics and emergence of panzootic 1 influenza viruses. PLoS Pathog. 2008, 4, e1000161. [CrossRef] [PubMed]

103. Smith, G.J.; Donis, R.O.; World Health Organization/World Organisation for Animal Health/Food; Agriculture Organization (WHO/OIE/FAO) H5 Evolution Working Group. Nomenclature updates resulting from the evolution of avian influenza a(h5) virus clades 2.1.3.2a, 2.2.1, and 2.3.4 during 2013-2014. Influenza Other Respir. Viruses 2015, 9, 271-276. [PubMed]

104. Arafa, A.S.; Yamada, S.; Imai, M.; Watanabe, T.; Yamayoshi, S.; Iwatsuki-Horimoto, K.; Kiso, M.; Sakai-Tagawa, Y.; Ito, M.; Imamura, T.; et al. Risk assessment of recent egyptian h5n1 influenza viruses. Sci. Rep. 2016, 6, 38388. [CrossRef] [PubMed]

105. Chen, Q.; Wang, H.; Zhao, L.; Ma, L.; Wang, R.; Lei, Y.; Li, Y.; Yang, G.; Chen, J.; Chen, G.; et al. First documented case of avian influenza (h5n1) virus infection in a lion. Emerg. Microbes Infect. 2016, 5, e125. [CrossRef] [PubMed]

106. He, S.; Shi, J.; Qi, X.; Huang, G.; Chen, H.; Lu, C. Lethal infection by a novel reassortant h5n1 avian influenza A virus in a zoo-housed tiger. Microbes Infect. 2015, 17, 54-61. [CrossRef] [PubMed]

107. Pabbaraju, K.; Tellier, R.; Wong, S.; Li, Y.; Bastien, N.; Tang, J.W.; Drews, S.J.; Jang, Y.; Davis, C.T.; Fonseca, K.; et al. Full-genome analysis of avian influenza a(h5n1) virus from a human, North America, 2013. Emerg. Infect. Dis. 2014, 20, 887-891. [CrossRef] [PubMed]

108. Bi, Y.; Chen, J.; Zhang, Z.; Li, M.; Cai, T.; Sharshov, K.; Susloparov, I.; Shestopalov, A.; Wong, G.; He, Y.; et al. Highly pathogenic avian influenza h5n1 clade 2.3.2.1c virus in migratory birds, 2014-2015. Virol. Sin. 2016, 31, 300-305. [CrossRef] [PubMed]

109. Naguib, M.M.; Kinne, J.; Chen, H.; Chan, K.H.; Joseph, S.; Wong, P.C.; Woo, P.C.; Wernery, R.; Beer, M.; Wernery, U.; et al. Outbreaks of highly pathogenic avian influenza h5n1 clade 2.3.2.1c in hunting falcons and kept wild birds in Dubai implicate intercontinental virus spread. J. Gen. Virol. 2015, 96, 3212. [CrossRef] [PubMed]

110. Dharmayanti, N.L.; Hartawan, R.; Pudjiatmoko Wibawa, H.; Hardiman Balish, A.; Donis, R.; Davis, C.T.; Samaan, G. Genetic characterization of clade 2.3.2.1 avian influenza a(h5n1) viruses, Indonesia, 2012. Emerg. Infect. Dis. 2014, 20, 671-674. [CrossRef] [PubMed]

111. Marinova-Petkova, A.; Feeroz, M.M.; Rabiul Alam, S.M.; Kamrul Hasan, M.; Akhtar, S.; Jones-Engel, L.; Walker, D.; McClenaghan, L.; Rubrum, A.; Franks, J.; et al. Multiple introductions of highly pathogenic avian influenza h5n1 viruses into Bangladesh. Emerg. Microbes Infect. 2014, 3, e11. [CrossRef] [PubMed]

112. Pan, M.; Gao, R.; Lv, Q.; Huang, S.; Zhou, Z.; Yang, L.; Li, X.; Zhao, X.; Zou, X.; Tong, W.; et al. Human infection with a novel, highly pathogenic avian influenza a (h5n6) virus: Virological and clinical findings. J. Infect. 2016, 72, 52-59. [CrossRef] [PubMed]

113. Yang, L.; Zhu, W.; Li, X.; Bo, H.; Zhang, Y.; Zou, S.; Gao, R.; Dong, J.; Zhao, X.; Chen, W.; et al. Genesis and dissemination of highly pathogenic H5N6 avian influenza viruses. J. Virol. 2017, 91. [CrossRef] [PubMed]

114. Du, Y.; Chen, M.; Yang, J.; Jia, Y.; Han, S.; Holmes, E.C.; Cui, J. Molecular evolution and emergence of h5n6 avian influenza virus in central China. J. Virol. 2017, 91, e00143-17. [CrossRef] [PubMed]

115. Zhang, Y.; Chen, M.; Huang, Y.; Zhu, W.; Yang, L.; Gao, L.; Li, X.; Bi, F.; Huang, C.; Kang, N.; et al. Human infections with novel reassortant h5n6 avian influenza viruses in China. Emerg. Microbes Infect. 2017, 6, e50. [CrossRef] [PubMed]

116. WHO. Avian Influenza Weekly Update Number 629. Available online: http://www.wpro.who.int/emergin g_diseases/ai_weekly_629_wpro_20180323.pdf (accessed on 19 July 2018). 
117. Gillim-Ross, L.; Santos, C.; Chen, Z.; Aspelund, A.; Yang, C.F.; Ye, D.; Jin, H.; Kemble, G.; Subbarao, K. Avian influenza h6 viruses productively infect and cause illness in mice and ferrets. J. Virol. 2008, 82, 10854-10863. [CrossRef] [PubMed]

118. Wei, S.H.; Yang, J.R.; Wu, H.S.; Chang, M.C.; Lin, J.S.; Lin, C.Y.; Liu, Y.L.; Lo, Y.C.; Yang, C.H.; Chuang, J.H.; et al. Human infection with avian influenza a h6n1 virus: An epidemiological analysis. Lancet Respir. Med. 2013, 1, 771-778. [CrossRef]

119. Lin, C.-Y.; Chia, M.-Y.; Chen, P.-L.; Yeh, C.-T.; Cheng, M.-C.; Su, I.-J.; Lee, M.-S. Assessment of pathogenicity and antigenicity of American lineage influenza h5n2 viruses in Taiwan. Virology 2017, 508, 159-163. [CrossRef] [PubMed]

120. Belser, J.A.; Bridges, C.B.; Katz, J.M.; Tumpey, T.M. Past, present, and possible future human infection with influenza virus A subtype H7. Emerg. Infect. Dis. 2009, 15, 859-865. [CrossRef] [PubMed]

121. Centers for Disease Control and Prevention (CDC). Prevention. Notes from the field: Highly pathogenic avian influenza a (h7n3) virus infection in two poultry workers-Jalisco, Mexico, July 2012. MMWR Morb. Mortal. Wkly. Rep. 2012, 61, 726-727.

122. Van Kolfschooten, F. Dutch veterinarian becomes first victim of avian influenza. Lancet 2003, $361,1444$. [CrossRef]

123. Puzelli, S.; Rossini, G.; Facchini, M.; Vaccari, G.; Di Trani, L.; Di Martino, A.; Gaibani, P.; Vocale, C.; Cattoli, G.; Bennett, M.; et al. Human infection with highly pathogenic a(h7n7) avian influenza virus, Italy, 2013. Emerg. Infect. Dis. 2014, 20, 1745-1749. [CrossRef] [PubMed]

124. Ke, C.; Mok, C.K.P.; Zhu, W.; Zhou, H.; He, J.; Guan, W.; Wu, J.; Song, W.; Wang, D.; Liu, J.; et al. Human Infection with Highly Pathogenic Avian Influenza a(h7n9) Virus, China. Emerg. Infect. Dis. 2017, 23, 1332-1340. [CrossRef] [PubMed]

125. Yang, L.; Zhu, W.; Li, X.; Chen, M.; Wu, J.; Yu, P.; Qi, S.; Huang, Y.; Shi, W.; Dong, J.; et al. Genesis and spread of newly emerged highly pathogenic h7n9 avian viruses in mainland China. J. Virol. 2017, 91. [CrossRef] [PubMed]

126. Yamayoshi, S.; Kiso, M.; Yasuhara, A.; Ito, M.; Shu, Y.; Kawaoka, Y. Enhanced replication of highly pathogenic influenza a(h7n9) virus in humans. Emerg. Infect. Dis. 2018, 24, 746-750. [CrossRef] [PubMed]

127. Guo, Z.; Xiao, D.; Li, D.; Wang, Y.; Yan, T.; Dai, B.; Wang, X. The temporal distribution of new h7n9 avian influenza infections based on laboratory-confirmed cases in Mainland China, 2013-2017. Sci. Rep. 2018, 8, 4051. [CrossRef] [PubMed]

128. Su, S.; Gu, M.; Liu, D.; Cui, J.; Gao, G.F.; Zhou, J.; Liu, X. Epidemiology, evolution, and pathogenesis of h7n9 influenza viruses in five epidemic waves since 2013 in China. Trends Microbiol. 2017, 25, 713-728. [CrossRef] [PubMed]

129. Li, C.; Wang, S.; Bing, G.; Carter, R.A.; Wang, Z.; Wang, J.; Wang, C.; Wang, L.; Wu, G.; Webster, R.G.; et al. Genetic evolution of influenza h9n2 viruses isolated from various hosts in China from 1994 to 2013. Emerg. Microbes Infect. 2017, 6, e106. [CrossRef] [PubMed]

130. Smietanka, K.; Minta, Z.; Swieton, E.; Olszewska, M.; Jozwiak, M.; Domanska-Blicharz, K.; Wyrostek, K.; Tomczyk, G.; Pikula, A. Avian influenza h9n2 subtype in Poland-characterization of the isolates and evidence of concomitant infections. Avian Pathol. 2014, 43, 427-436. [CrossRef] [PubMed]

131. Aamir, U.B.; Wernery, U.; Ilyushina, N.; Webster, R.G. Characterization of avian h9n2 influenza viruses from United Arab Emirates 2000 to 2003. Virology 2007, 361, 45-55. [CrossRef] [PubMed]

132. Matrosovich, M.N.; Krauss, S.; Webster, R.G. H9n2 influenza A viruses from poultry in Asia have human virus-like receptor specificity. Virology 2001, 281, 156-162. [CrossRef] [PubMed]

133. Kim, S.H. Challenge for One Health: Co-Circulation of Zoonotic h5n1 and h9n2 avian influenza viruses in Egypt. Viruses 2018, 10, 121. [CrossRef] [PubMed]

134. El Houadfi, M.; Fellahi, S.; Nassik, S.; Guerin, J.L.; Ducatez, M.F. First outbreaks and phylogenetic analyses of avian influenza h9n2 viruses isolated from poultry flocks in Morocco. Virol. J. 2016, 13, 140. [CrossRef] [PubMed]

135. Nagy, A.; Mettenleiter, T.C.; Abdelwhab, E.M. A brief summary of the epidemiology and genetic relatedness of avian influenza h9n2 virus in birds and mammals in the Middle East and North Africa. Epidemiol. Infect. 2017, 145, 3320-3333. [CrossRef] [PubMed]

136. Gu, M.; Xu, L.; Wang, X.; Liu, X. Current situation of h9n2 subtype avian influenza in China. Vet. Res. 2017, 48, 49. [CrossRef] [PubMed] 
137. Li, X.; Tian, B.; Jianfang, Z.; Yongkun, C.; Xiaodan, L.; Wenfei, Z.; Yan, L.; Jing, T.; Junfeng, G.; Tao, C.; et al. A comprehensive retrospective study of the seroprevalence of h9n2 avian influenza viruses in occupationally exposed populations in China. PLoS ONE 2017, 12, e0178328. [CrossRef] [PubMed]

138. Yuan, R.; Liang, L.; Wu, J.; Kang, Y.; Song, Y.; Zou, L.; Zhang, X.; Ni, H.; Ke, C. Human infection with an avian influenza a/h9n2 virus in Guangdong in 2016. J. Infect. 2017, 74, 422-425. [CrossRef] [PubMed]

139. Wu, Z.Q.; Zhang, Y.; Zhao, N.; Yu, Z.; Pan, H.; Chan, T.C.; Zhang, Z.R.; Liu, S.L. Comparative epidemiology of human fatal infections with novel, high (h5n6 and h5n1) and low (h7n9 and h9n2) pathogenicity avian influenza A viruses. Int. J. Environ. Res. Public Health 2017, 14, 263. [CrossRef] [PubMed]

140. Marinova-Petkova, A.; Franks, J.; Tenzin, S.; Dahal, N.; Dukpa, K.; Dorjee, J.; Feeroz, M.M.; Rehg, J.E.; Barman, S.; Krauss, S.; et al. Highly pathogenic reassortant avian influenza a(h5n1) virus clade 2.3.2.1a in poultry, bhutan. Emerg. Infect. Dis. 2016, 22, 2137-2141. [CrossRef] [PubMed]

141. Wu, H.; Peng, X.; Peng, X.; Cheng, L.; Lu, X.; Jin, C.; Xie, T.; Yao, H.; Wu, N. Genetic and molecular characterization of $\mathrm{h} 9 \mathrm{n} 2$ and h5 avian influenza viruses from live poultry markets in Zhejiang Province, eastern China. Sci. Rep. 2015, 5, 17508. [CrossRef] [PubMed]

142. Yuan, R.; Zou, L.; Kang, Y.; Wu, J.; Zeng, X.; Lu, J.; Liang, L.; Song, Y.; Zhang, X.; Ni, H.; et al. Reassortment of Avian Influenza A/H6N6 Viruses from Live Poultry Markets in Guangdong, China. Front. Microbiol. 2016, 7, 65. [CrossRef] [PubMed]

143. Arzey, G.G.; Kirkland, P.D.; Arzey, K.E.; Frost, M.; Maywood, P.; Conaty, S.; Hurt, A.C.; Deng, Y.M.; Iannello, P.; Barr, I.; et al. Influenza virus A (H10N7) in chickens and poultry abattoir workers, Australia. Emerg. Infect. Dis. 2012, 18, 814-816. [CrossRef] [PubMed]

144. Van den Brand, J.M.; Wohlsein, P.; Herfst, S.; Bodewes, R.; Pfankuche, V.M.; van de Bildt, M.W.; Seehusen, F.; Puff, C.; Richard, M.; Siebert, U.; et al. Influenza A (H10N7) Virus Causes Respiratory Tract Disease in Harbor Seals and Ferrets. PLoS ONE 2016, 11, e0159625.

145. Bodewes, R.; Bestebroer, T.M.; van der Vries, E.; Verhagen, J.H.; Herfst, S.; Koopmans, M.P.; Fouchier, R.A.; Pfankuche, V.M.; Wohlsein, P.; Siebert, U.; et al. Avian Influenza A(H10N7) virus-associated mass deaths among harbor seals. Emerg. Infect. Dis. 2015, 21, 720-722. [CrossRef] [PubMed]

146. Dittrich, A.; Scheibner, D.; Salaheldin, A.H.; Veits, J.; Gischke, M.; Mettenleiter, T.C.; Abdelwhab, E.M. Impact of Mutations in the Hemagglutinin of H10N7 Viruses Isolated from Seals on Virus Replication in Avian and Human Cells. Viruses 2018, 10, 83. [CrossRef] [PubMed]

147. Lai, S.; Qin, Y.; Cowling, B.J.; Ren, X.; Wardrop, N.A.; Gilbert, M.; Tsang, T.K.; Wu, P.; Feng, L.; Jiang, H.; et al. Global epidemiology of avian influenza A H5N1 virus infection in humans, 1997-2015: A systematic review of individual case data. Lancet Infect. Dis. 2016, 16, e108-e118. [CrossRef]

148. Vong, S.; Ly, S.; Van Kerkhove, M.D.; Achenbach, J.; Holl, D.; Buchy, P.; Sorn, S.; Seng, H.; Uyeki, T.M.; Sok, T.; et al. Risk factors associated with subclinical human infection with avian influenza A (H5N1) virus-Cambodia, 2006. J. Infect. Dis. 2009, 199, 1744-1752. [CrossRef] [PubMed]

149. Wang, X.; Jiang, H.; Wu, P.; Uyeki, T.M.; Feng, L.; Lai, S.; Wang, L.; Huo, X.; Xu, K.; Chen, E.; et al. Epidemiology of avian influenza A H7N9 virus in human beings across five epidemics in mainland China, 2013-2017: An epidemiological study of laboratory-confirmed case series. Lancet Infect. Dis. 2017, 17, 822-832. [CrossRef]

150. Belser, J.A.; Lash, R.R.; Garg, S.; Tumpey, T.M.; Maines, T.R. The eyes have it: Influenza virus infection beyond the respiratory tract. Lancet Infect. Dis. 2018, 18, e220-e227. [CrossRef]

151. Pfeiffer, D.U.; Otte, M.J.; Roland-Holst, D.; Zilberman, D. A one health perspective on HPAI H5N1 in the Greater Mekong sub-region. Comp. Immunol. Microbiol. Infect. Dis. 2013, 36, 309-319. [CrossRef] [PubMed]

152. Yi, L.; Guan, D.; Kang, M.; Wu, J.; Zeng, X.; Lu, J.; Rutherford, S.; Zou, L.; Liang, L.; Ni, H.; et al. Family clusters of avian influenza A H7N9 virus infection in Guangdong Province, China. J. Clin. Microbiol. 2015, 53, 22-28. [CrossRef] [PubMed]

153. Olsen, S.J.; Ungchusak, K.; Sovann, L.; Uyeki, T.M.; Dowell, S.F.; Cox, N.J.; Aldis, W.; Chunsuttiwat, S. Family clustering of avian influenza A (H5N1). Emerg. Infect. Dis. 2005, 11, 1799-1801. [CrossRef] [PubMed]

154. Abdelwhab, E.M.; Hafez, H.M. An overview of the epidemic of highly pathogenic H5N1 avian influenza virus in Egypt: Epidemiology and control challenges. Epidemiol. Infect. 2011, 139, 647-657. [CrossRef] [PubMed] 
155. Van Kerkhove, M.D.; Mumford, E.; Mounts, A.W.; Bresee, J.; Ly, S.; Bridges, C.B.; Otte, J. Highly pathogenic avian influenza (h5n1): Pathways of exposure at the animal-human interface, a systematic review. PLoS ONE 2011, 6, e14582. [CrossRef] [PubMed]

156. Khan, S.U.; Anderson, B.D.; Heil, G.L.; Liang, S.; Gray, G.C. A Systematic Review and Meta-Analysis of the Seroprevalence of Influenza a(h9n2) Infection Among Humans. J. Infect. Dis. 2015, 212, 562-569. [CrossRef] [PubMed]

157. Wang, Q.; Ju, L.; Liu, P.; Zhou, J.; Lv, X.; Li, L.; Shen, H.; Su, H.; Jiang, L.; Jiang, Q. Serological and virological surveillance of avian influenza a virus h9n2 subtype in humans and poultry in Shanghai, China, between 2008 and 2010. Zoonoses Public Health 2015, 62, 131-140. [CrossRef] [PubMed]

158. Fragaszy, E.; Ishola, D.A.; Brown, I.H.; Enstone, J.; Nguyen-Van-Tam, J.S.; Simons, R.; Tucker, A.W.; Wieland, B.; Williamson, S.M.; Hayward, A.C.; et al. Increased risk of A(H1N1)pdm09 influenza infection in UK pig industry workers compared to a general population cohort. Influenza Other Respir. Viruses 2016, 10, 291-300. [CrossRef] [PubMed]

159. Siembieda, J.; Johnson, C.K.; Boyce, W.; Sandrock, C.; Cardona, C. Risk for avian influenza virus exposure at human-wildlife interface. Emerg. Infect. Dis. 2008, 14, 1151-1153. [CrossRef] [PubMed]

160. Gray, G.C.; Ferguson, D.D.; Lowther, P.E.; Heil, G.L.; Friary, J.A. A national study of us bird banders for evidence of avian influenza virus infections. J. Clin. Virol. 2011, 51, 132-135. [CrossRef] [PubMed]

161. Hoffmann, E.; Krauss, S.; Perez, D.; Webby, R.; Webster, R.G. Eight-plasmid system for rapid generation of influenza virus vaccines. Vaccine 2002, 20, 3165-3170. [CrossRef]

162. Mostafa, A.; Kanrai, P.; Petersen, H.; Ibrahim, S.; Rautenschlein, S.; Pleschka, S. Efficient generation of recombinant influenza A viruses employing a new approach to overcome the genetic instability of ha segments. PLoS ONE 2015, 10, e0116917. [CrossRef] [PubMed]

163. Mostafa, A.; Kanrai, P.; Ziebuhr, J.; Pleschka, S. Improved dual promotor-driven reverse genetics system for influenza viruses. J. Virol. Methods 2013, 193, 603-610. [CrossRef] [PubMed]

164. Reperant, L.A.; Kuiken, T.; Osterhaus, A.D. Adaptive pathways of zoonotic influenza viruses: From exposure to establishment in humans. Vaccine 2012, 30, 4419-4434. [CrossRef] [PubMed]

165. Cui, J.; Qu, N.; Guo, Y.; Cao, L.; Wu, S.; Mei, K.; Sun, H.; Lu, Y.; Qin, Z.; Jiao, P.; et al. Phylogeny, pathogenicity, and transmission of h5n1 avian influenza viruses in chickens. Front. Cell. Infect. Microbiol. 2017, 7, 328. [CrossRef] [PubMed]

166. Kandeil, A.; El-Shesheny, R.; Maatouq, A.; Moatasim, Y.; Cai, Z.; McKenzie, P.; Webby, R.; Kayali, G.; Ali, M.A. Novel reassortant $h 9 n 2$ viruses in pigeons and evidence for antigenic diversity of $h 9 n 2$ viruses isolated from quails in Egypt. J. Gen. Virol. 2017, 98, 548-562. [CrossRef] [PubMed]

167. Xue, R.; Tian, Y.; Hou, T.; Bao, D.; Chen, H.; Teng, Q.; Yang, J.; Li, X.; Wang, G.; Li, Z.; et al. H9n2 influenza virus isolated from minks has enhanced virulence in mice. Transbound. Emerg. Dis. 2018, 65, 904-910. [CrossRef] [PubMed]

168. Cauldwell, A.V.; Long, J.S.; Moncorge, O.; Barclay, W.S. Viral determinants of influenza A virus host range. J. Gen. Virol. 2014, 95, 1193-1210. [CrossRef] [PubMed]

169. Liu, Q.; Qiao, C.; Marjuki, H.; Bawa, B.; Ma, J.; Guillossou, S.; Webby, R.J.; Richt, J.A.; Ma, W. Combination of PB2 271A and SR polymorphism at positions 590/591 is critical for viral replication and virulence of swine influenza virus in cultured cells and in vivo. J. Virol. 2012, 86, 1233-1237. [CrossRef] [PubMed]

170. Song, W.; Wang, P.; Mok, B.W.; Lau, S.Y.; Huang, X.; Wu, W.L.; Zheng, M.; Wen, X.; Yang, S.; Chen, Y.; et al. The K526R substitution in viral protein PB2 enhances the effects of E627K on influenza virus replication. Nat. Commun. 2014, 5, 5509. [CrossRef] [PubMed]

171. Mok, C.K.; Yen, H.L.; Yu, M.Y.; Yuen, K.M.; Sia, S.F.; Chan, M.C.; Qin, G.; Tu, W.W.; Peiris, J.S. Amino acid residues 253 and 591 of the PB2 protein of avian influenza virus a h9n2 contribute to mammalian pathogenesis. J. Virol. 2011, 85, 9641-9645. [CrossRef] [PubMed]

172. Shinya, K.; Hamm, S.; Hatta, M.; Ito, H.; Ito, T.; Kawaoka, Y. PB2 amino acid at position 627 affects replicative efficiency, but not cell tropism, of Hong Kong H5N1 influenza A viruses in mice. Virology 2004, 320, 258-266. [CrossRef] [PubMed]

173. Hatta, M.; Gao, P.; Halfmann, P.; Kawaoka, Y. Molecular basis for high virulence of Hong Kong H5N1 influenza A viruses. Science 2001, 293, 1840-1842. [CrossRef] [PubMed]

174. Massin, P.; van der Werf, S.; Naffakh, N. Residue 627 of PB2 is a determinant of cold sensitivity in RNA replication of avian influenza viruses. J. Virol. 2001, 75, 5398-5404. [CrossRef] [PubMed] 
175. Hatta, M.; Hatta, Y.; Kim, J.H.; Watanabe, S.; Shinya, K.; Nguyen, T.; Lien, P.S.; Le, Q.M.; Kawaoka, Y. Growth of H5N1 influenza A viruses in the upper respiratory tracts of mice. PLoS Pathog. 2007, 3, 1374-1379. [CrossRef] [PubMed]

176. Steel, J.; Lowen, A.C.; Mubareka, S.; Palese, P. Transmission of influenza virus in a mammalian host is increased by PB2 amino acids 627K or 627E/701N. PLoS Pathog. 2009, 5, e1000252. [CrossRef] [PubMed]

177. Zhu, H.; Wang, J.; Wang, P.; Song, W.; Zheng, Z.; Chen, R.; Guo, K.; Zhang, T.; Peiris, J.S.; Chen, H.; et al. Substitution of lysine at 627 position in PB2 protein does not change virulence of the 2009 pandemic H1N1 virus in mice. Virology 2010, 401, 1-5. [CrossRef] [PubMed]

178. Taubenberger, J.K.; Reid, A.H.; Lourens, R.M.; Wang, R.; Jin, G.; Fanning, T.G. Characterization of the 1918 influenza virus polymerase genes. Nature 2005, 437, 889-893. [CrossRef] [PubMed]

179. Kocer, Z.A.; Fan, Y.; Huether, R.; Obenauer, J.; Webby, R.J.; Zhang, J.; Webster, R.G.; Wu, G. Survival analysis of infected mice reveals pathogenic variations in the genome of avian H1N1 viruses. Sci. Rep. 2014, 4, 7455. [CrossRef] [PubMed]

180. Kawaoka, Y.; Krauss, S.; Webster, R.G. Avian-to-human transmission of the PB1 gene of influenza A viruses in the 1957 and 1968 pandemics. J. Virol. 1989, 63, 4603-4608. [PubMed]

181. Pappas, C.; Aguilar, P.V.; Basler, C.F.; Solorzano, A.; Zeng, H.; Perrone, L.A.; Palese, P.; Garcia-Sastre, A.; Katz, J.M.; Tumpey, T.M. Single gene reassortants identify a critical role for PB1, HA, and NA in the high virulence of the 1918 pandemic influenza virus. Proc. Natl. Acad. Sci. USA 2008, 105, 3064-3069. [CrossRef] [PubMed]

182. Wendel, I.; Rubbenstroth, D.; Doedt, J.; Kochs, G.; Wilhelm, J.; Staeheli, P.; Klenk, H.D.; Matrosovich, M. The avian-origin pb1 gene segment facilitated replication and transmissibility of the h3n2/1968 pandemic influenza virus. J. Virol. 2015. [CrossRef] [PubMed]

183. McAuley, J.L.; Chipuk, J.E.; Boyd, K.L.; Van De Velde, N.; Green, D.R.; McCullers, J.A. PB1-F2 proteins from H5N1 and 20 century pandemic influenza viruses cause immunopathology. PLoS Pathog. 2010, 6, e1001014. [CrossRef] [PubMed]

184. Conenello, G.M.; Zamarin, D.; Perrone, L.A.; Tumpey, T.; Palese, P. A single mutation in the PB1-F2 of H5N1 (HK/97) and 1918 influenza A viruses contributes to increased virulence. PLoS Pathog. 2007, 3, 1414-1421. [CrossRef] [PubMed]

185. Song, M.S.; Pascua, P.N.; Lee, J.H.; Baek, Y.H.; Lee, O.J.; Kim, C.J.; Kim, H.; Webby, R.J.; Webster, R.G.; Choi, Y.K. The polymerase acidic protein gene of influenza a virus contributes to pathogenicity in a mouse model. J. Virol. 2009, 83, 12325-12335. [CrossRef] [PubMed]

186. Bussey, K.A.; Desmet, E.A.; Mattiacio, J.L.; Hamilton, A.; Bradel-Tretheway, B.; Bussey, H.E.; Kim, B.; Dewhurst, S.; Takimoto, T. PA residues in the 2009 H1N1 pandemic influenza virus enhance avian influenza virus polymerase activity in mammalian cells. J. Virol. 2011, 85, 7020-7028. [CrossRef] [PubMed]

187. Xu, G.; Zhang, X.; Gao, W.; Wang, C.; Wang, J.; Sun, H.; Sun, Y.; Guo, L.; Zhang, R.; Chang, K.C.; et al. Prevailing pa mutation k356r in avian influenza h9n2 virus increases mammalian replication and pathogenicity. J. Virol. 2016, 90, 8105-8114. [CrossRef] [PubMed]

188. Mehle, A.; Dugan, V.G.; Taubenberger, J.K.; Doudna, J.A. Reassortment and mutation of the avian influenza virus polymerase PA subunit overcome species barriers. J. Virol. 2012, 86, 1750-1757. [CrossRef] [PubMed]

189. Jagger, B.W.; Wise, H.M.; Kash, J.C.; Walters, K.A.; Wills, N.M.; Xiao, Y.L.; Dunfee, R.L.; Schwartzman, L.M.; Ozinsky, A.; Bell, G.L.; et al. An overlapping protein-coding region in influenza A virus segment 3 modulates the host response. Science 2012, 337, 199-204. [CrossRef] [PubMed]

190. Xiao, H.; Killip, M.J.; Staeheli, P.; Randall, R.E.; Jackson, D. The human interferon-induced MxA protein inhibits early stages of influenza A virus infection by retaining the incoming viral genome in the cytoplasm. J. Virol. 2013, 87, 13053-13058. [CrossRef] [PubMed]

191. Nigg, P.E.; Pavlovic, J. Oligomerization and gtp-binding requirements of $m x a$ for viral target recognition and antiviral activity against influenza a virus. J. Biol. Chem. 2015, 290, 29893-29906. [CrossRef] [PubMed]

192. Dittmann, J.; Stertz, S.; Grimm, D.; Steel, J.; Garcia-Sastre, A.; Haller, O.; Kochs, G. Influenza A virus strains differ in sensitivity to the antiviral action of Mx-GTPase. J. Virol. 2008, 82, 3624-3631. [CrossRef] [PubMed]

193. Zimmermann, P.; Manz, B.; Haller, O.; Schwemmle, M.; Kochs, G. The viral nucleoprotein determines Mx sensitivity of influenza A viruses. J. Virol. 2011, 85, 8133-8140. [CrossRef] [PubMed] 
194. Manz, B.; Dornfeld, D.; Gotz, V.; Zell, R.; Zimmermann, P.; Haller, O.; Kochs, G.; Schwemmle, M. Pandemic influenza A viruses escape from restriction by human MxA through adaptive mutations in the nucleoprotein. PLoS Pathog. 2013, 9, e1003279. [CrossRef] [PubMed]

195. Riegger, D.; Hai, R.; Dornfeld, D.; Manz, B.; Leyva-Grado, V.; Sanchez-Aparicio, M.T.; Albrecht, R.A.; Palese, P.; Haller, O.; Schwemmle, M.; et al. The nucleoprotein of newly emerged H7N9 influenza A virus harbors a unique motif conferring resistance to antiviral human MxA. J. Virol. 2015, 89, 2241-2252. [CrossRef] [PubMed]

196. Gotz, V.; Magar, L.; Dornfeld, D.; Giese, S.; Pohlmann, A.; Hoper, D.; Kong, B.W.; Jans, D.A.; Beer, M.; Haller, O.; et al. Influenza A viruses escape from MxA restriction at the expense of efficient nuclear vRNP import. Sci. Rep. 2016, 6, 23138. [CrossRef] [PubMed]

197. Ashenberg, O.; Padmakumar, J.; Doud, M.B.; Bloom, J.D. Deep mutational scanning identifies sites in influenza nucleoprotein that affect viral inhibition by MxA. PLoS Pathog. 2017, 13, e1006288. [CrossRef] [PubMed]

198. Hutchinson, E.C.; Fodor, E. Nuclear import of the influenza A virus transcriptional machinery. Vaccine 2012, 30, 7353-7358. [CrossRef] [PubMed]

199. Goldfarb, D.S.; Corbett, A.H.; Mason, D.A.; Harreman, M.T.; Adam, S.A. Importin alpha: A multipurpose nuclear-transport receptor. Trends Cell Biol. 2004, 14, 505-514. [CrossRef] [PubMed]

200. Wu, W.; Sankhala, R.S.; Florio, T.J.; Zhou, L.; Nguyen, N.L.T.; Lokareddy, R.K.; Cingolani, G.; Pante, N. Synergy of two low-affinity NLSs determines the high avidity of influenza A virus nucleoprotein NP for human importin alpha isoforms. Sci. Rep. 2017, 7, 11381. [CrossRef] [PubMed]

201. O’Neill, R.E.; Jaskunas, R.; Blobel, G.; Palese, P.; Moroianu, J. Nuclear import of influenza virus RNA can be mediated by viral nucleoprotein and transport factors required for protein import. J. Biol. Chem. 1995, 270, 22701-22704. [CrossRef] [PubMed]

202. Mukaigawa, J.; Nayak, D.P. Two signals mediate nuclear localization of influenza virus (A/WSN/33) polymerase basic protein 2. J. Virol. 1991, 65, 245-253. [PubMed]

203. Nath, S.T.; Nayak, D.P. Function of two discrete regions is required for nuclear localization of polymerase basic protein 1 of A/WSN/33 influenza virus (H1 N1). Mol. Cell. Biol. 1990, 10, 4139-4145. [CrossRef] [PubMed]

204. Nieto, A.; de la Luna, S.; Barcena, J.; Portela, A.; Ortin, J. Complex structure of the nuclear translocation signal of influenza virus polymerase PA subunit. J. Gen. Virol. 1994, 75, 29-36. [CrossRef] [PubMed]

205. Gabriel, G.; Herwig, A.; Klenk, H.D. Interaction of polymerase subunit PB2 and NP with importin alpha1 is a determinant of host range of influenza A virus. PLoS Pathog. 2008, 4, e11. [CrossRef] [PubMed]

206. Bertram, S.; Thiele, S.; Dreier, C.; Resa-Infante, P.; Preuss, A.; van Riel, D.; Mok, C.K.P.; Schwalm, F.; Peiris, J.S.M.; Klenk, H.D.; et al. H7n9 influenza a virus exhibits importin-alpha7-mediated replication in the mammalian respiratory tract. Am. J. Pathol. 2017, 187, 831-840. [CrossRef] [PubMed]

207. Gabriel, G.; Klingel, K.; Otte, A.; Thiele, S.; Hudjetz, B.; Arman-Kalcek, G.; Sauter, M.; Shmidt, T.; Rother, F.; Baumgarte, S.; et al. Differential use of importin- $\alpha$ isoforms governs cell tropism and host adaptation of influenza virus. Nat. Commun. 2011, 2, 156. [CrossRef] [PubMed]

208. Hudjetz, B.; Gabriel, G. Human-like pb2 627k influenza virus polymerase activity is regulated by importin- $\alpha 1$ and $-\alpha$ 7. PLoS Pathog. 2012, 8, e1002488. [CrossRef] [PubMed]

209. Jiang, S.; Li, R.; Du, L.; Liu, S. Roles of the hemagglutinin of influenza A virus in viral entry and development of antiviral therapeutics and vaccines. Protein Cell 2010, 1, 342-354. [CrossRef] [PubMed]

210. Kido, H.; Yokogoshi, Y.; Sakai, K.; Tashiro, M.; Kishino, Y.; Fukutomi, A.; Katunuma, N. Isolation and characterization of a novel trypsin-like protease found in rat bronchiolar epithelial Clara cells. A possible activator of the viral fusion glycoprotein. J. Biol. Chem. 1992, 267, 13573-13579. [PubMed]

211. Bottcher-Friebertshauser, E.; Garten, W.; Matrosovich, M.; Klenk, H.D. The hemagglutinin: A determinant of pathogenicity. Curr. Top. Microbiol. Immunol. 2014, 385, 3-34. [PubMed]

212. Franca, M.; Stallknecht, D.E.; Howerth, E.W. Expression and distribution of sialic acid influenza virus receptors in wild birds. Avian Pathol. 2013, 42, 60-71. [CrossRef] [PubMed]

213. Suzuki, Y.; Ito, T.; Suzuki, T.; Holland, R.E., Jr.; Chambers, T.M.; Kiso, M.; Ishida, H.; Kawaoka, Y. Sialic acid species as a determinant of the host range of influenza A viruses. J. Virol. 2000, 74, 11825-11831. [CrossRef] [PubMed] 
214. Kumlin, U.; Olofsson, S.; Dimock, K.; Arnberg, N. Sialic acid tissue distribution and influenza virus tropism. Influenza Other Respir. Viruses 2008, 2, 147-154. [CrossRef] [PubMed]

215. Shinya, K.; Ebina, M.; Yamada, S.; Ono, M.; Kasai, N.; Kawaoka, Y. Avian flu: Influenza virus receptors in the human airway. Nature 2006, 440, 435-436. [CrossRef] [PubMed]

216. Ito, T.; Couceiro, J.N.; Kelm, S.; Baum, L.G.; Krauss, S.; Castrucci, M.R.; Donatelli, I.; Kida, H.; Paulson, J.C.; Webster, R.G.; et al. Molecular basis for the generation in pigs of influenza A viruses with pandemic potential. J. Virol. 1998, 72, 7367-7373. [PubMed]

217. Wan, H.; Perez, D.R. Quail carry sialic acid receptors compatible with binding of avian and human influenza viruses. Virology 2006, 346, 278-286. [CrossRef] [PubMed]

218. Mair, C.M.; Ludwig, K.; Herrmann, A.; Sieben, C. Receptor binding and pH stability-How influenza A virus hemagglutinin affects host-specific virus infection. Biochim. Biophys. Acta 2014, 1838, 1153-1168. [CrossRef] [PubMed]

219. Myers, J.L.; Wetzel, K.S.; Linderman, S.L.; Li, Y.; Sullivan, C.B.; Hensley, S.E. Compensatory hemagglutinin mutations alter antigenic properties of influenza viruses. J. Virol. 2013, 87, 11168-11172. [CrossRef] [PubMed]

220. Ayora-Talavera, G.; Shelton, H.; Scull, M.A.; Ren, J.; Jones, I.M.; Pickles, R.J.; Barclay, W.S. Mutations in H5N1 influenza virus hemagglutinin that confer binding to human tracheal airway epithelium. PLoS ONE 2009, 4, e7836. [CrossRef] [PubMed]

221. Kim, J.I.; Lee, I.; Park, S.; Lee, S.; Hwang, M.W.; Bae, J.Y.; Heo, J.; Kim, D.; Jang, S.I.; Song, J.W.; et al. Effects of a hemagglutinin D222G substitution on the pathogenicity of 2009 influenza A (H1N1) virus in mice. Arch. Virol. 2014, 159, 2559-2565. [CrossRef] [PubMed]

222. Stieneke-Grober, A.; Vey, M.; Angliker, H.; Shaw, E.; Thomas, G.; Roberts, C.; Klenk, H.D.; Garten, W. Influenza virus hemagglutinin with multibasic cleavage site is activated by furin, a subtilisin-like endoprotease. EMBO J. 1992, 11, 2407-2414. [CrossRef] [PubMed]

223. Luczo, J.M.; Stambas, J.; Durr, P.A.; Michalski, W.P.; Bingham, J. Molecular pathogenesis of H5 highly pathogenic avian influenza: The role of the haemagglutinin cleavage site motif. Rev. Med. Virol. 2015, 25, 406-430. [CrossRef] [PubMed]

224. Callan, R.J.; Hartmann, F.A.; West, S.E.; Hinshaw, V.S. Cleavage of influenza A virus H1 hemagglutinin by swine respiratory bacterial proteases. J. Virol. 1997, 71, 7579-7585. [PubMed]

225. Zhirnov, O.P.; Ikizler, M.R.; Wright, P.F. Cleavage of influenza a virus hemagglutinin in human respiratory epithelium is cell associated and sensitive to exogenous antiproteases. J. Virol. 2002, 76, 8682-8689. [CrossRef] [PubMed]

226. Bertram, S.; Glowacka, I.; Steffen, I.; Kuhl, A.; Pohlmann, S. Novel insights into proteolytic cleavage of influenza virus hemagglutinin. Rev. Med. Virol. 2010, 20, 298-310. [CrossRef] [PubMed]

227. Chutinimitkul, S.; Herfst, S.; Steel, J.; Lowen, A.C.; Ye, J.; van Riel, D.; Schrauwen, E.J.; Bestebroer, T.M.; Koel, B.; Burke, D.F.; et al. Virulence-associated substitution D222G in the hemagglutinin of 2009 pandemic influenza A(H1N1) virus affects receptor binding. J. Virol. 2010, 84, 11802-11813. [CrossRef] [PubMed]

228. Schrauwen, E.J.; Fouchier, R.A. Host adaptation and transmission of influenza A viruses in mammals. Emerg. Microbes Infect. 2014, 3, e9. [CrossRef] [PubMed]

229. Imai, M.; Watanabe, T.; Hatta, M.; Das, S.C.; Ozawa, M.; Shinya, K.; Zhong, G.; Hanson, A.; Katsura, H.; Watanabe, S.; et al. Experimental adaptation of an influenza H5 HA confers respiratory droplet transmission to a reassortant $\mathrm{H} 5 \mathrm{HA} / \mathrm{H} 1 \mathrm{~N} 1$ virus in ferrets. Nature 2012, 486, 420-428. [CrossRef] [PubMed]

230. Herfst, S.; Schrauwen, E.J.; Linster, M.; Chutinimitkul, S.; de Wit, E.; Munster, V.J.; Sorrell, E.M.; Bestebroer, T.M.; Burke, D.F.; Smith, D.J.; et al. Airborne transmission of influenza A/H5N1 virus between ferrets. Science 2012, 336, 1534-1541. [CrossRef] [PubMed]

231. Sutton, T.C.; Finch, C.; Shao, H.; Angel, M.; Chen, H.; Capua, I.; Cattoli, G.; Monne, I.; Perez, D.R. Airborne transmission of highly pathogenic H7N1 influenza virus in ferrets. J. Virol. 2014, 88, 6623-6635. [CrossRef] [PubMed]

232. Schmier, S.; Mostafa, A.; Haarmann, T.; Bannert, N.; Ziebuhr, J.; Veljkovic, V.; Dietrich, U.; Pleschka, S. In silico prediction and experimental confirmation of HA residues conferring enhanced human receptor specificity of H5N1 influenza A viruses. Sci. Rep. 2015, 5, 11434. [CrossRef] [PubMed]

233. Mitnaul, L.J.; Matrosovich, M.N.; Castrucci, M.R.; Tuzikov, A.B.; Bovin, N.V.; Kobasa, D.; Kawaoka, Y. Balanced hemagglutinin and neuraminidase activities are critical for efficient replication of influenza A virus. J. Virol. 2000, 74, 6015-6020. [CrossRef] [PubMed] 
234. Xu, R.; Zhu, X.; McBride, R.; Nycholat, C.M.; Yu, W.; Paulson, J.C.; Wilson, I.A. Functional balance of the hemagglutinin and neuraminidase activities accompanies the emergence of the 2009 H1N1 influenza pandemic. J. Virol. 2012, 86, 9221-9232. [CrossRef] [PubMed]

235. Baum, L.G.; Paulson, J.C. The N2 neuraminidase of human influenza virus has acquired a substrate specificity complementary to the hemagglutinin receptor specificity. Virology 1991, 180, 10-15. [CrossRef]

236. Kobasa, D.; Kodihalli, S.; Luo, M.; Castrucci, M.R.; Donatelli, I.; Suzuki, Y.; Suzuki, T.; Kawaoka, Y. Amino acid residues contributing to the substrate specificity of the influenza A virus neuraminidase. J. Virol. 1999, 73, 6743-6751. [PubMed]

237. Zhou, H.; Yu, Z.; Hu, Y.; Tu, J.; Zou, W.; Peng, Y.; Zhu, J.; Li, Y.; Zhang, A.; Yu, Z.; et al. The special neuraminidase stalk-motif responsible for increased virulence and pathogenesis of H5N1 influenza A virus. PLoS ONE 2009, 4, e6277. [CrossRef] [PubMed]

238. Sorrell, E.M.; Song, H.; Pena, L.; Perez, D.R. A 27-amino-acid deletion in the neuraminidase stalk supports replication of an avian H2N2 influenza A virus in the respiratory tract of chickens. J. Virol. 2010, 84, 11831-11840. [CrossRef] [PubMed]

239. Sun, Y.; Tan, Y.; Wei, K.; Sun, H.; Shi, Y.; Pu, J.; Yang, H.; Gao, G.F.; Yin, Y.; Feng, W.; et al. Amino acid 316 of hemagglutinin and the neuraminidase stalk length influence virulence of $\mathrm{h} 9 \mathrm{n} 2$ influenza virus in chickens and mice. J. Virol. 2013, 87, 2963-2968. [CrossRef] [PubMed]

240. Hoffmann, T.W.; Munier, S.; Larcher, T.; Soubieux, D.; Ledevin, M.; Esnault, E.; Tourdes, A.; Croville, G.; Guerin, J.L.; Quere, P.; et al. Length variations in the NA stalk of an H7N1 influenza virus have opposite effects on viral excretion in chickens and ducks. J. Virol. 2012, 86, 584-588. [CrossRef] [PubMed]

241. Blumenkrantz, D.; Roberts, K.L.; Shelton, H.; Lycett, S.; Barclay, W.S. The short stalk length of highly pathogenic avian influenza H5N1 virus neuraminidase limits transmission of pandemic H1N1 virus in ferrets. J. Virol. 2013, 87, 10539-10551. [CrossRef] [PubMed]

242. Marc, D. Influenza virus non-structural protein NS1: Interferon antagonism and beyond. J. Gen. Virol. 2014, 95, 2594-2611. [CrossRef] [PubMed]

243. Rivas, H.G.; Schmaling, S.K.; Gaglia, M.M. Shutoff of host gene expression in influenza a virus and herpesviruses: Similar mechanisms and common themes. Viruses 2016, 8, 102. [CrossRef] [PubMed]

244. Ma, W.; Brenner, D.; Wang, Z.; Dauber, B.; Ehrhardt, C.; Hogner, K.; Herold, S.; Ludwig, S.; Wolff, T.; $\mathrm{Yu}, \mathrm{K}$; ; et al. The NS segment of an H5N1 highly pathogenic avian influenza virus (HPAIV) is sufficient to alter replication efficiency, cell tropism, and host range of an H7N1 HPAIV. J. Virol. 2010, 84, 2122-2133. [CrossRef] [PubMed]

245. Wang, Z.; Robb, N.C.; Lenz, E.; Wolff, T.; Fodor, E.; Pleschka, S. NS reassortment of an H7-type highly pathogenic avian influenza virus affects its propagation by altering the regulation of viral RNA production and antiviral host response. J. Virol. 2010, 84, 11323-11335. [CrossRef] [PubMed]

246. Kanrai, P.; Mostafa, A.; Madhugiri, R.; Lechner, M.; Wilk, E.; Schughart, K.; Ylosmaki, L.; Saksela, K.; Ziebuhr, J.; Pleschka, S. Identification of specific residues in avian influenza A virus NS1 that enhance viral replication and pathogenicity in mammalian systems. J. Gen. Virol. 2016, 97, 2135-2148. [CrossRef] [PubMed]

247. Burgui, I.; Aragon, T.; Ortin, J.; Nieto, A. PABP1 and eIF4GI associate with influenza virus NS1 protein in viral mRNA translation initiation complexes. J. Gen. Virol. 2003, 84, 3263-3274. [CrossRef] [PubMed]

248. Falcon, A.M.; Marion, R.M.; Zurcher, T.; Gomez, P.; Portela, A.; Nieto, A.; Ortin, J. Defective RNA replication and late gene expression in temperature-sensitive influenza viruses expressing deleted forms of the NS1 protein. J. Virol. 2004, 78, 3880-3888. [CrossRef] [PubMed]

249. Dankar, S.K.; Miranda, E.; Forbes, N.E.; Pelchat, M.; Tavassoli, A.; Selman, M.; Ping, J.; Jia, J.; Brown, E.G. Influenza A/Hong Kong/156/1997(H5N1) virus NS1 gene mutations F103L and M106I both increase IFN antagonism, virulence and cytoplasmic localization but differ in binding to RIG-I and CPSF30. Virol. J. 2013, 10, 243. [CrossRef] [PubMed]

250. Seo, S.H.; Hoffmann, E.; Webster, R.G. The NS1 gene of H5N1 influenza viruses circumvents the host anti-viral cytokine responses. Virus Res. 2004, 103, 107-113. [CrossRef] [PubMed]

251. Zhou, H.; Jin, M.; Chen, H.; Huag, Q.; Yu, Z. Genome-sequence analysis of the pathogenic H5N1 avian influenza A virus isolated in China in 2004. Virus Genes 2006, 32, 85-95. [CrossRef] [PubMed]

252. Long, J.X.; Peng, D.X.; Liu, Y.L.; Wu, Y.T.; Liu, X.F. Virulence of H5N1 avian influenza virus enhanced by a 15-nucleotide deletion in the viral nonstructural gene. Virus Genes 2008, 36, 471-478. [CrossRef] [PubMed] 
253. Zhu, Q.; Yang, H.; Chen, W.; Cao, W.; Zhong, G.; Jiao, P.; Deng, G.; Yu, K.; Yang, C.; Bu, Z.; et al. A naturally occurring deletion in its NS gene contributes to the attenuation of an H5N1 swine influenza virus in chickens. J. Virol. 2008, 82, 220-228. [CrossRef] [PubMed]

254. Hale, B.G.; Steel, J.; Medina, R.A.; Manicassamy, B.; Ye, J.; Hickman, D.; Hai, R.; Schmolke, M.; Lowen, A.C.; Perez, D.R.; et al. Inefficient control of host gene expression by the 2009 pandemic H1N1 influenza A virus NS1 protein. J. Virol. 2010, 84, 6909-6922. [CrossRef] [PubMed]

255. Clark, A.M.; Nogales, A.; Martinez-Sobrido, L.; Topham, D.J.; DeDiego, M.L. Functional evolution of influenza virus ns1 protein in currently circulating human 2009 pandemic H1N1 viruses. J. Virol. 2017, 91. [CrossRef] [PubMed]

256. Jackson, D.; Hossain, M.J.; Hickman, D.; Perez, D.R.; Lamb, R.A. A new influenza virus virulence determinant: The NS1 protein four C-terminal residues modulate pathogenicity. Proc. Natl. Acad. Sci. USA 2008, 105, 4381-4386. [CrossRef] [PubMed]

257. Hale, B.G.; Steel, J.; Manicassamy, B.; Medina, R.A.; Ye, J.; Hickman, D.; Lowen, A.C.; Perez, D.R.; Garcia-Sastre, A. Mutations in the NS1 C-terminal tail do not enhance replication or virulence of the 2009 pandemic H1N1 influenza A virus. J. Gen. Virol. 2010, 91, 1737-1742. [CrossRef] [PubMed]

258. Kumar, M.; Liu, H.; Rice, A.P. Regulation of interferon-beta by MAGI-1 and its interaction with influenza A virus NS1 protein with ESEV PBM. PLoS ONE 2012, 7, e41251. [CrossRef]

259. Petersen, H.; Mostafa, A.; Tantawy, M.A.; Iqbal, A.A.; Hoffmann, D.; Tallam, A.; Selvakumar, B.; Pessler, F.; Beer, M.; Rautenschlein, S.; et al. NS segment of a 1918 influenza a virus-descendent enhances replication of h1n1pdm09 and virus-induced cellular immune response in mammalian and avian systems. Front. Microbiol. 2018, 9. [CrossRef] [PubMed]

260. Houser, K.; Subbarao, K. Influenza Vaccines: Challenges and Solutions. Cell Host Microbe 2015, 17, $295-300$. [CrossRef] [PubMed]

261. Ozaki, H.; Govorkova, E.A.; Li, C.; Xiong, X.; Webster, R.G.; Webby, R.J. Generation of high-yielding influenza A viruses in African green monkey kidney (Vero) cells by reverse genetics. J. Virol. 2004, 78, 1851-1857. [CrossRef] [PubMed]

262. Wood, J.M.; Williams, M.S. History of inactivated influenza vaccines. In Textbook of Influenza; Nicholson, K.G., Webster, R.G., Hay, A.J., Eds.; Blackwell Science Ltd.: Oxford, UK, 1998; pp. 317-323.

263. Subbarao, K.; Chen, H.; Swayne, D.; Mingay, L.; Fodor, E.; Brownlee, G.; Xu, X.; Lu, X.; Katz, J.; Cox, N.; et al. Evaluation of a genetically modified reassortant $\mathrm{H} 5 \mathrm{~N} 1$ influenza A virus vaccine candidate generated by plasmid-based reverse genetics. Virology 2003, 305, 192-200. [CrossRef] [PubMed]

264. Schickli, J.H.; Flandorfer, A.; Nakaya, T.; Martinez-Sobrido, L.; Garcia-Sastre, A.; Palese, P. Plasmid-only rescue of influenza A virus vaccine candidates. Philos. Trans. R. Soc. Lond. Ser. B Biol. Sci. 2001, 356, 1965-1973.

265. Hu, W.; Zhang, H.; Han, Q.; Li, L.; Chen, Y.; Xia, N.; Chen, Z.; Shu, Y.; Xu, K.; Sun, B. A Vero-cell-adapted vaccine donor strain of influenza A virus generated by serial passages. Vaccine 2015, 33, 374-381. [CrossRef] [PubMed]

266. Kandeil, A.; Sabir, J.S.M.; Abdelaal, A.; Mattar, E.H.; El-Taweel, A.N.; Sabir, M.J.; Khalil, A.A.; Webby, R.; Kayali, G.; Ali, M.A. Efficacy of commercial vaccines against newly emerging avian influenza H5N8 virus in Egypt. Sci. Rep. 2018, 8, 9697. [CrossRef] [PubMed]

267. Kayali, G.; Kandeil, A.; El-Shesheny, R.; Kayed, A.S.; Gomaa, M.R.; Kutkat, M.A.; Debeauchamp, J.; McKenzie, P.P.; Webster, R.G.; Webby, R.J.; et al. Do commercial avian influenza H5 vaccines induce cross-reactive antibodies against contemporary H5N1 viruses in Egypt? Poult. Sci. 2013, 92, 114-118. [CrossRef] [PubMed]

268. Kitikoon, P.; Gauger, P.C.; Anderson, T.K.; Culhane, M.R.; Swenson, S.; Loving, C.L.; Perez, D.R.; Vincent, A.L. Swine influenza virus vaccine serologic cross-reactivity to contemporary US swine H3N2 and efficacy in pigs infected with an H3N2 similar to 2011-2012 H3N2v. Influenza Other Respir. Viruses 2013, 7, 32-41. [CrossRef] [PubMed]

269. Capua, I.; Alexander, D.J. Avian influenza vaccines and vaccination in birds. Vaccine 2008, 26, D70-D73. [CrossRef] [PubMed] 
270. Loving, C.L.; Lager, K.M.; Vincent, A.L.; Brockmeier, S.L.; Gauger, P.C.; Anderson, T.K.; Kitikoon, P.; Perez, D.R.; Kehrli, M.E. Efficacy in pigs of inactivated and live attenuated influenza virus vaccines against infection and transmission of an emerging h3n2 similar to the 2011-2012 h3n2v. J. Virol. 2013, 87, 9895-9903. [CrossRef] [PubMed]

271. Tarigan, S.; Wibowo, M.H.; Indriani, R.; Sumarningsih, S.; Artanto, S.; Idris, S.; Durr, P.A.; Asmara, W.; Ebrahimie, E.; Stevenson, M.A.; et al. Field effectiveness of highly pathogenic avian influenza H5N1 vaccination in commercial layers in Indonesia. PLoS ONE 2018, 13, e0190947. [CrossRef] [PubMed]

272. Kandeil, A.; Mostafa, A.; El-Shesheny, R.; El-Taweel, A.N.; Gomaa, M.; Galal, H.; Kayali, G.; Ali, M.A. Avian influenza H5N1 vaccination efficacy in Egyptian backyard poultry. Vaccine 2017, 35, 6195-6201. [CrossRef] [PubMed]

273. Abdelwhab, E.M.; Hafez, H.M. Insight into alternative approaches for control of avian influenza in poultry, with emphasis on highly pathogenic h5n1. Viruses 2012, 4, 3179-3208. [CrossRef] [PubMed]

274. CDC. Prevention and Treatment of Avian Influenza A Viruses in People. Available online: https:/ /www.cdc. gov/flu/avianflu/prevention.htm (accessed on 20 July 2018).

275. Wong, S.S.; Webby, R.J. Traditional and new influenza vaccines. Clin. Microbiol. Rev. 2013, 26, 476-492. [CrossRef] [PubMed]

276. McNicholl, I.R.; McNicholl, J.J. Neuraminidase inhibitors: Zanamivir and oseltamivir. Ann. Pharmacother. 2001, 35, 57-70. [CrossRef] [PubMed]

277. Paules, C.; Subbarao, K. Influenza. Lancet 2017, 390, 697-708. [CrossRef]

278. Koszalka, P.; Tilmanis, D.; Hurt, A.C. Influenza antivirals currently in late-phase clinical trial. Influenza Other Respir. Viruses 2017, 11, 240-246. [CrossRef] [PubMed]

279. Li, T.C.; Chan, M.C.; Lee, N. Clinical implications of antiviral resistance in influenza. Viruses 2015, 7, 4929-4944. [CrossRef] [PubMed]

280. Belshe, R.B.; Smith, M.H.; Hall, C.B.; Betts, R.; Hay, A.J. Genetic basis of resistance to rimantadine emerging during treatment of influenza virus infection. J. Virol. 1988, 62, 1508-1512. [PubMed]

281. Hu, Y.; Musharrafieh, R.; Ma, C.; Zhang, J.; Smee, D.F.; DeGrado, W.F.; Wang, J. An M2-V27A channel blocker demonstrates potent in vitro and in vivo antiviral activities against amantadine-sensitive and-Resistant influenza A viruses. Antivir Res. 2017, 140, 45-54. [CrossRef] [PubMed]

282. El-Shesheny, R.; Bagato, O.; Kandeil, A.; Mostafa, A.; Mahmoud, S.H.; Hassanneen, H.M.; Webby, R.J.; Ali, M.A.; Kayali, G. Re-emergence of amantadine-resistant variants among highly pathogenic avian influenza H5N1 viruses in Egypt. Infect. Genet. Evol. 2016, 46, 102-109. [CrossRef] [PubMed]

283. Hussain, M.; Galvin, H.D.; Haw, T.Y.; Nutsford, A.N.; Husain, M. Drug resistance in influenza A virus: The epidemiology and management. Infect. Drug Resist. 2017, 10, 121-134. [CrossRef] [PubMed]

284. Dong, G.; Peng, C.; Luo, J.; Wang, C.; Han, L.; Wu, B.; Ji, G.; He, H. Adamantane-resistant influenza A viruses in the world (1902-2013): Frequency and distribution of $\mathrm{m} 2$ gene mutations. PLoS ONE 2015, 10, e0119115. [CrossRef] [PubMed]

285. CDC. Influenza Antiviral Drug Resistance. 2018. Available online: https://www.cdc.gov/flu/about/qa/an tiviralresistance.htm (accessed on 3 August 2018).

286. Abdelwhab, E.M.; Veits, J.; Mettenleiter, T.C. Biological fitness and natural selection of amantadine resistant variants of avian influenza H5N1 viruses. Virus Res. 2017, 228, 109-113. [CrossRef] [PubMed]

287. Beigel, J.H.; Voell, J.; Munoz, P.; Kumar, P.; Brooks, K.M.; Zhang, J.; Iversen, P.; Heald, A.; Wong, M.; Davey, R.T. Safety, tolerability, and pharmacokinetics of radavirsen (AVI-7100), an antisense oligonucleotide targeting influenza a M1/M2 translation. Br. J. Clin. Pharmacol. 2018, 84, 25-34. [CrossRef] [PubMed]

288. Colman, P.M. Influenza virus neuraminidase: Structure, antibodies, and inhibitors. Protein Sci. 1994, 3 , 1687-1696. [CrossRef] [PubMed]

289. Colman, P.M.; Varghese, J.N.; Laver, W.G. Structure of the catalytic and antigenic sites in influenza virus neuraminidase. Nature 1983, 303, 41-44. [CrossRef] [PubMed]

290. Choi, W.S.; Jeong, J.H.; Kwon, J.J.; Ahn, S.J.; Lloren, K.K.S.; Kwon, H.I.; Chae, H.B.; Hwang, J.; Kim, M.H.; Kim, C.J.; et al. Screening for neuraminidase inhibitor resistance markers among avian influenza viruses of the N4, N5, N6, and N8 neuraminidase subtypes. J. Virol. 2018, 92. [CrossRef] [PubMed]

291. Tu, V.; Abed, Y.; Fage, C.; Baz, M.; Boivin, G. Impact of R152K and R368K neuraminidase catalytic substitutions on in vitro properties and virulence of recombinant $\mathrm{A}(\mathrm{H} 1 \mathrm{~N} 1) \mathrm{pdm} 09$ viruses. Antivir. Res. 2018, 154, 110-115. [CrossRef] [PubMed] 
292. Gubareva, L.V.; Kaiser, L.; Hayden, F.G. Influenza virus neuraminidase inhibitors. Lancet 2000, 355, 827-835. [CrossRef]

293. Yamashita, M.; Tomozawa, T.; Kakuta, M.; Tokumitsu, A.; Nasu, H.; Kubo, S. CS-8958, a prodrug of the new neuraminidase inhibitor R-125489, shows long-acting anti-influenza virus activity. Antimicrob. Agents Chemother. 2009, 53, 186-192. [CrossRef] [PubMed]

294. Fiore, A.E.; Fry, A.; Shay, D.; Gubareva, L.; Bresee, J.S.; Uyeki, T.M.; Centers for Disease Control and Prevention (CDC). Antiviral agents for the treatment and chemoprophylaxis of influenza-Recommendations of the Advisory Committee on Immunization Practices (ACIP). MMWR Recomm. Rep. 2011, 60, 1-24. [PubMed]

295. McKimm-Breschkin, J.L. Influenza neuraminidase inhibitors: Antiviral action and mechanisms of resistance. Influenza Other Respir Viruses 2013, 7 (Suppl. 1), 25-36. [CrossRef] [PubMed]

296. McKimm-Breschkin, J.L.; Barrett, S.; Wong, F.Y.K.; Pudjiatmoko; Azhar, M.; Selleck, P.; Davies, K.R.; Hartaningsih, N.; McGrane, J. Identification of Indonesian clade 2.1 highly pathogenic influenza a(h5n1) viruses with N294S and S246N neuraminidase substitutions which further reduce oseltamivir susceptibility. Antiviral Res. 2018, 153, 95-100. [PubMed]

297. McKimm-Breschkin, J.L.; Barrett, S.; Pudjiatmoko; Azhar, M.; Wong, F.Y.K.; Selleck, P.; Mohr, P.G.; McGrane, J.; Kim, M. I222 Neuraminidase mutations further reduce oseltamivir susceptibility of indonesian clade 2.1 highly pathogenic avian influenza a(h5n1) viruses. PLoS ONE 2013, 8, e66105. [CrossRef]

298. Myoung-don, O.; Rabeh, E.-S.; Mohamed, A.K.; Ahmed, K.; Ahmed, M.; Mariette, F.D.; Pamela, M.; Elena, A.G.; Mohamed, H.N.; Robert, G.W.; et al. Continuing threat of influenza (H5N1) virus circulation in Egypt. Emerg. Infect. Dis. J. 2011, 17, 2306. [CrossRef]

299. Yen, H.L.; McKimm-Breschkin, J.L.; Choy, K.T.; Wong, D.D.; Cheung, P.P.; Zhou, J.; Ng, I.H.; Zhu, H.; Webby, R.J.; Guan, Y.; et al. Resistance to neuraminidase inhibitors conferred by an R292K mutation in a human influenza virus H7N9 isolate can be masked by a mixed R/K viral population. mBio 2013, 4 . [CrossRef] [PubMed]

300. Ikematsu, H.; Kawai, N.; Iwaki, N.; Kashiwagi, S.; Ishikawa, Y.; Yamaguchi, H.; Shiosakai, K. In vitro neuraminidase inhibitory concentration $\left(\mathrm{IC}_{50}\right)$ of four neuraminidase inhibitors in the Japanese 2016-2017 season: Comparison with the 2010-2011 to 2015-2016 seasons. J. Infect. Chemother. 2018. [CrossRef]

301. Govorkova Elena, A. Consequences of resistance: In vitro fitness, in vivo infectivity, and transmissibility of oseltamivir-resistant influenza A viruses. Influenza Other Respir. Viruses 2012, 7, 50-57. [CrossRef] [PubMed]

302. Butler, J.; Hooper, K.A.; Petrie, S.; Lee, R.; Maurer-Stroh, S.; Reh, L.; Guarnaccia, T.; Baas, C.; Xue, L.; Vitesnik, S.; et al. Estimating the fitness advantage conferred by permissive neuraminidase mutations in recent oseltamivir-resistant $\mathrm{A}(\mathrm{H} 1 \mathrm{~N} 1)$ pdm09 influenza viruses. PLoS Pathog. 2014, 10, e1004065. [CrossRef] [PubMed]

303. Marjuki, H.; Mishin, V.P.; Chesnokov, A.P.; De La Cruz, J.A.; Davis, C.T.; Villanueva, J.M.; Fry, A.M.; Gubareva, L.V. Neuraminidase mutations conferring resistance to oseltamivir in influenza a(h7n9) viruses. J. Virol. 2015, 89, 5419-5426. [CrossRef] [PubMed]

304. Baek, Y.H.; Song, M.S.; Lee, E.Y.; Kim, Y.I.; Kim, E.H.; Park, S.J.; Park, K.J.; Kwon, H.I.; Pascua, P.N.; Lim, G.J.; et al. Profiling and characterization of influenza virus N1 strains potentially resistant to multiple neuraminidase inhibitors. J. Virol. 2015, 89, 287-299. [CrossRef] [PubMed]

305. Leung, K.; Lipsitch, M.; Yuen, K.Y.; Wu, J.T. Monitoring the fitness of antiviral-resistant influenza strains during an epidemic: A mathematical modeling study. Lancet Infect. Dis. 2017, 17, 339-347. [CrossRef]

306. Scheuch, G.; Canisius, S.; Nocker, K.; Hofmann, T.; Naumann, R.; Pleschka, S.; Ludwig, S.; Welte, T.; Planz, O. Targeting intracellular signaling as an antiviral strategy: Aerosolized LASAG for the treatment of influenza in hospitalized patients. Emerg. Microbes. Infect. 2018, 7, 21. [CrossRef] [PubMed]

307. Haasbach, E.; Muller, C.; Ehrhardt, C.; Schreiber, A.; Pleschka, S.; Ludwig, S.; Planz, O. The MEK-inhibitor CI-1040 displays a broad anti-influenza virus activity in vitro and provides a prolonged treatment window compared to standard of care in vivo. Antivir. Res. 2017, 142, 178-184. [CrossRef] [PubMed]

308. Schrader, T.; Dudek, S.E.; Schreiber, A.; Ehrhardt, C.; Planz, O.; Ludwig, S. The clinically approved MEK inhibitor Trametinib efficiently blocks influenza A virus propagation and cytokine expression. Antivir. Res. 2018, 157, 80-92. [CrossRef] [PubMed]

309. WHO. Overview of Amino Acid Substitutions in Influenza Neuraminidase Associated with Resistance or Reduced Susceptibility to NAIs. Available online: http:/ / www.who.int/influenza/gisrs_laboratory/antivi ral_susceptibility/en/ (accessed on 24 July 2018). 
310. Kwon, J.J.; Choi, W.S.; Jeong, J.H.; Kim, E.H.; Lee, O.J.; Yoon, S.W.; Hwang, J.; Webby, R.J.; Govorkova, E.A.; Choi, Y.K.; et al. An I436N substitution confers resistance of influenza A(H1N1)pdm09 viruses to multiple neuraminidase inhibitors without affecting viral fitness. J. Gen. Virol. 2018, 99, 292-302. [CrossRef] [PubMed]

311. Huang, W.; Cheng, Y.; Li, X.; Tan, M.; Wei, H.; Zhao, X.; Xiao, N.; Dong, J.; Wang, D. Neuraminidase inhibitor susceptibility profile of human influenza viruses during the 2016-2017 influenza season in Mainland China. J. Infect. Chemother. 2018. [CrossRef] [PubMed]

312. Verhagen, J.H.; Lexmond, P.; Vuong, O.; Schutten, M.; Guldemeester, J.; Osterhaus, A.D.M.E.; Elbers, A.R.W.; Slaterus, R.; Hornman, M.; Koch, G.; et al. Discordant detection of avian influenza virus subtypes in time and space between poultry and wild birds; Towards improvement of surveillance programs. PLoS ONE 2017, 12, e0173470. [CrossRef] [PubMed]

313. Kadam, R.U.; Wilson, I.A. Structural basis of influenza virus fusion inhibition by the antiviral drug Arbidol. Proc. Natl. Acad. Sci. USA 2017, 114, 206-214. [CrossRef] [PubMed]

314. Nguyen, J.T.; Hoopes, J.D.; Smee, D.F.; Prichard, M.N.; Driebe, E.M.; Engelthaler, D.M.; Le, M.H.; Keim, P.S.; Spence, R.P.; Went, G.T. Triple combination of oseltamivir, amantadine, and ribavirin displays synergistic activity against multiple influenza virus strains in vitro. Antimicrob. Agents Chemother. 2009, 53, 4115-4126. [CrossRef] [PubMed]

315. Droebner, K.; Haasbach, E.; Dudek, S.E.; Scheuch, G.; Nocker, K.; Canisius, S.; Ehrhardt, C.; von Degenfeld, G.; Ludwig, S.; Planz, O. Pharmacodynamics, pharmacokinetics, and antiviral activity of bay 81-8781, a novel nf-kappab inhibiting anti-influenza drug. Front. Microbiol. 2017, 8, 2130. [CrossRef] [PubMed]

(C) 2018 by the authors. Licensee MDPI, Basel, Switzerland. This article is an open access article distributed under the terms and conditions of the Creative Commons Attribution (CC BY) license (http:/ / creativecommons.org/licenses/by/4.0/). 